\title{
Metathesis reactivity of bis(phosphinite) pincer ligated nickel chloride, isothiocyanate and azide complexes
}

\author{
Huizhen Li ${ }^{\mathrm{a}}$, Wenjuan Meng ${ }^{\mathrm{a}}$, Anubendu Adhikary ${ }^{\mathrm{b}}$, Shujun Li ${ }^{\mathrm{a}}$, Nana Ma ${ }^{\mathrm{a}}$, Qianyi \\ Zhao ${ }^{\mathrm{a}}$, Qiuyu Yang ${ }^{\mathrm{a}}$, Nathan A. Eberhardt ${ }^{\mathrm{b}}$, Kendra M. Leahy ${ }^{\mathrm{b}}$, Jeanette A. Krause ${ }^{\mathrm{b}}$, \\ Jie Zhang ${ }^{*, a}$, Xuenian Chen ${ }^{*, a}$, Hairong Guan *,b \\ ${ }^{a}$ School of Chemistry and Chemical Engineering, Henan Normal University, Xinxiang, \\ Henan 453007, China \\ ${ }^{\mathrm{b}}$ Department of Chemistry, University of Cincinnati, P. O. Box 210172, Cincinnati, \\ OH 45221-0172, USA \\ E-mails: jie.zhang@htu.edu.cn (J.Z.); xnchen@htu.edu.cn (X.C.); \\ hairong.guan@uc.edu (H.G.)
}

Abstract: A series of nickel pincer complexes of the type [4-Z-2,6- $\left.\left(\mathrm{R}_{2} \mathrm{PO}\right)_{2} \mathrm{C}_{6} \mathrm{H}_{2}\right] \mathrm{NiX}$ $\left(\mathrm{R}={ }^{\mathrm{t}} \mathrm{Bu},{ }^{\mathrm{i}} \mathrm{Pr}, \mathrm{Ph} ; \mathrm{Z}=\mathrm{H}, \mathrm{CO}_{2} \mathrm{Me} ; \mathrm{X}=\underline{\mathrm{NCS}}, \mathrm{N}_{3}\right)$ have been synthesized from the reactions of the corresponding nickel chloride complexes $\left[4-\mathrm{Z}-2,6-\left(\mathrm{R}_{2} \mathrm{PO}\right)_{2} \mathrm{C}_{6} \mathrm{H}_{2}\right] \mathrm{NiCl}$ and potassium thiocyanate or sodium azide. X-ray structure determinations of these complexes have shown that the thiocyanate ion binds to the nickel center through the nitrogen. A comparable $\mathrm{Ni}-\mathrm{N}$ bond length (approx. $1.87 \AA$ for the isothiocyanate complexes and $1.91 \AA$ for the azide complexes) and an almost identical $\mathrm{Ni}-\mathrm{C}_{\text {ipso }}$ bond length (approx. $1.89 \AA$ ) have been observed for these complexes. Metathesis reactivity of $\left[4-\mathrm{Z}-2,6-\left(\mathrm{R}_{2} \mathrm{PO}\right)_{2} \mathrm{C}_{6} \mathrm{H}_{2}\right] \mathrm{NiCl}$ and ligand exchange reactions between the nickel isothiocyanate and nickel azide complexes have been investigated. The metathesis reactions with thiocyanate/azide complexes are faster with a less electron rich and more sterically accessible nickel center. The thermodynamic stability of these nickel complexes has been rationalized using the hard-soft acid-base theory (HSAB theory); a harder ligand prefers a less electron rich nickel center. These 
experimental results have been supported by quantum chemical analysis of the coordinating nitrogen atoms in $\mathrm{SCN}^{-}$and $\mathrm{N}_{3}^{-}$.

Keywords: Metathesis reaction, Synthesis, Crystal structure, Nickel, Pincer complex

\section{Introduction}

Transition metal complexes bearing a bis(phosphinite) pincer or POCOP-pincer ligand have been extensively studied since the first reports by Jensen [1] and Bedford [2]. This specific class of complexes has been demonstrated as efficient catalysts for a wide range of chemical transformations [3]. The popularity of using these complexes for catalysis has been largely attributed to the high catalyst thermal stability [4], well balanced ligand properties [5] and convenient ligand synthesis [1,2,4a,6]. During the past decade, significant effort has focused on the elucidation of structure-reactivity relationships with the goal of developing more active catalysts [7].

We are particularly interested in nickel complexes supported by a POCOP-pincer ligand, and our efforts have led to the development of catalysts for the reduction of aldehydes [8a], ketones [8a], $\mathrm{CO}_{2}$ [8b-e], cyanomethylation of aldehydes [8f] and $\mathrm{C}-\mathrm{S}$ cross-coupling reactions $[8 \mathrm{~g}]$. To gain a deeper understanding of how structural modification could change the performance of these complexes in different catalytic reactions, we have carried out detailed studies about substituent effects on the reactivity of the metal center. In one of our recent studies, we have reported how the substituents on the phosphorus donors influence the $\mathrm{Ni}-\mathrm{S}$ bond dissociation energies and kinetic stability of nickel arylthiolate complexes [9]. The electrostatic component of the bonding appears to contribute greatly to the strength of the Ni-S bond. To explore the generality of this conclusion, herein we extend the chemistry to nickel POCOP-pincer complexes bearing a nitrogen-based ligand. More specifically, we have focused on the metathesis reactivity of $\left[4-\mathrm{Z}-2,6-\left(\mathrm{R}_{2} \mathrm{PO}\right)_{2} \mathrm{C}_{6} \mathrm{H}_{2}\right] \mathrm{NiX}(\mathrm{Z}=\mathrm{H}$, $\left.\mathrm{CO}_{2} \mathrm{Me} ; \mathrm{R}={ }^{\mathrm{t}} \mathrm{Bu},{ }^{\mathrm{i}} \mathrm{Pr}, \mathrm{Ph} ; \mathrm{X}=\mathrm{Cl}, \underline{\mathrm{NCS}}, \mathrm{N}_{3}\right)$. The introduction of an ester group to the pincer backbone has also allowed us to probe how the remote ligand modification would impact the bond breaking/forming processes. 


\section{Results and discussion}

Synthesis and structure of nickel pincer complexes

Following previously reported procedures for the synthesis of $\left[2,6-\left({ }^{\mathrm{t}} \mathrm{Bu}_{2} \mathrm{PO}\right)_{2} \mathrm{C}_{6} \mathrm{H}_{3}\right] \mathrm{NiCl} \quad(\mathbf{1 a a}) \quad[8 \mathrm{a}], \quad\left[2,6-\left({ }^{\mathrm{i}} \mathrm{Pr}_{2} \mathrm{PO}\right)_{2} \mathrm{C}_{6} \mathrm{H}_{3}\right] \mathrm{NiCl} \quad(\mathbf{1 a b}) \quad[6 \mathrm{c}]$ and $\left[2,6-\left(\mathrm{Ph}_{2} \mathrm{PO}\right)_{2} \mathrm{C}_{6} \mathrm{H}_{3}\right] \mathrm{NiCl}$ (1ac) [6b], complexes 1ba-c were synthesized via cyclometalation of the ester-substituted diphosphinite ligand with $\mathrm{NiCl}_{2}$ (eq 1). Complex 1bb was reported by Zargarian and co-workers, who developed a one-pot procedure for preparing complexes of this type from resorcinol or its derivatives, $\mathrm{R}_{2} \mathrm{PCl}$ and nickel powder [10]. The new complexes $\mathbf{1 b a}$ and $\mathbf{1 b c}$ were characterized by ${ }^{1} \mathrm{H}$ NMR, ${ }^{31} \mathrm{P}\left\{{ }^{1} \mathrm{H}\right\} \mathrm{NMR},{ }^{13} \mathrm{C}\left\{{ }^{1} \mathrm{H}\right\}$ NMR and elemental analysis. The structure of 1ba was also confirmed by X-ray crystallography (see Appendix B. Supplementary data).

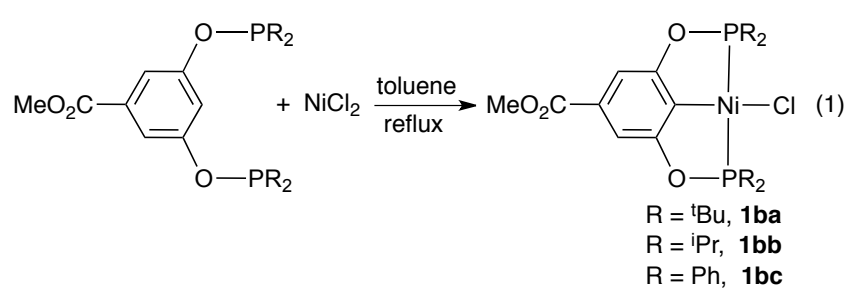

Room temperature reactions of nickel chloride complexes 1 with 5 equiv of potassium thiocyanate afforded nickel isothiocyanate complexes 2 in high isolated yields (86-93\%) (Scheme 1). Thiocyanate ion is a well-known ambidentate ligand. Depending on the polarizability and the steric environment of the metal, thiocyanate ligand can bind to the metal through either the sulfur or the nitrogen end, resulting in a thiocyanate or isothiocyanate complex. In this study, there was no evidence for sulfur binding; the isothiocyanate complex was isolated as the sole product in all cases, as suggested by X-ray structure analysis of the single crystals as well as the ${ }^{31} \mathrm{P}\left\{{ }^{1} \mathrm{H}\right\}$ NMR spectrum in which only one resonance was observed.

Similarly, mixing nickel chloride complexes 1 with 5 equiv of sodium azide in THF/MeOH (1: 1) for several days yielded nickel azide complexes 3 (Scheme 1). 
Complex 3ab was previously reported by Zargarian et al. through the reaction of the corresponding trimethylsiloxide complex with $\mathrm{Me}_{3} \mathrm{SiN}_{3}[7 \mathrm{~m}]$. Related nickel azide complexes bearing a $\mathrm{POC}_{\mathrm{sp} 3} \mathrm{OP}$-pincer ligand [7m] or a PCP-pincer ligand [11] were prepared in a similar fashion using $\mathrm{Me}_{3} \mathrm{SiN}_{3}$.

To accelerate the substitution of the chloride ligand in complex 1 by $\mathrm{SCN}^{-}$and $\mathrm{N}_{3}^{-}$, each of the reactions shown in Scheme 1 was conducted under refluxing conditions. However, an extra recrystallization step was needed to ensure the purity of the products, which resulted in lower isolated yields (60-78\%) than those for the room temperature reactions.

The nickel isothiocyanate and azide complexes reported here are all air and moisture stable in both solution and solid states. No significant decomposition was observed when a solid sample or a solution (in $\mathrm{CH}_{2} \mathrm{Cl}_{2} / n$-hexane) was exposed to the air for a few weeks.

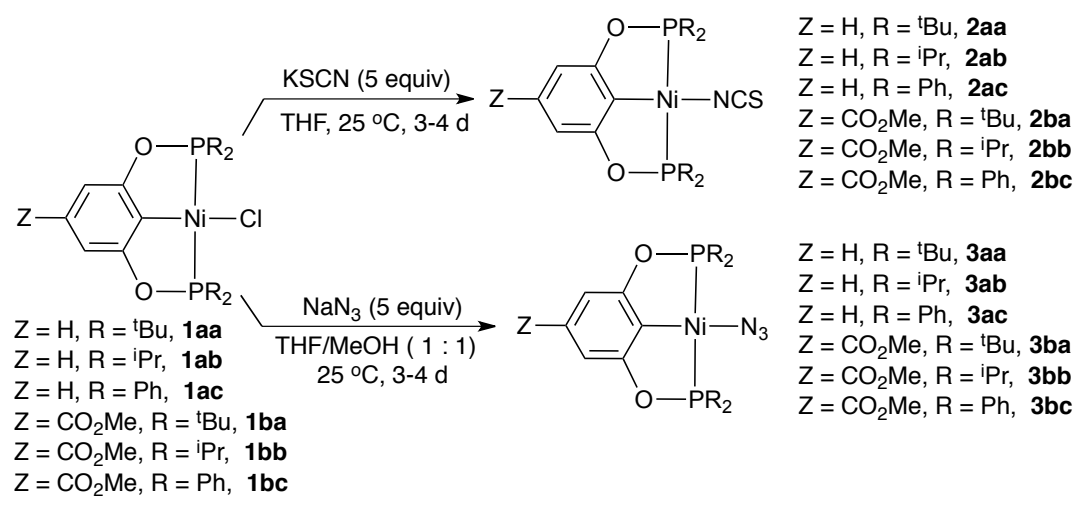

Scheme 1. Synthesis of POCOP pincer ligated nickel isothiocyanate and azide complexes

The new nickel isothiocyanate and azide complexes were fully characterized by multinuclear NMR, FTIR, X-ray crystallography and elemental analysis. Notable features of the ${ }^{13} \mathrm{C}\left\{{ }^{1} \mathrm{H}\right\}$ NMR spectra included the ipso carbons appearing as triplets $\left({ }^{2} J_{\mathrm{P}-\mathrm{C}}=20-25 \mathrm{~Hz}\right)$ at $123.86-125.37 \mathrm{ppm}$ for 2aa-c and 3aa-c, and 131.35-133.25 ppm for 2 ba-c and 3ba-c. The chemical shift differences for the ipso carbons can be attributed to the electronic effects of the para-substituents $\left(\mathrm{H}\right.$ vs. $\left.\mathrm{CO}_{2} \mathrm{Me}\right)$. The electron-withdrawing ester group makes the ipso carbons more deshielded, leading to a downfield shift of 6-9 ppm. All ${ }^{31} \mathrm{P}\left\{{ }^{1} \mathrm{H}\right\}$ NMR spectra displayed a single 
resonance, consistent with a symmetrical structure bearing two equivalent phosphorus atoms. For complexes with the same phosphorus substituents (R groups) and the same ancillary ligand $\left(\mathrm{NCS}^{-}\right.$or $\left.\mathrm{N}_{3}^{-}\right)$, the resonances for the $\mathrm{CO}_{2} \mathrm{Me}$-substituted complexes were located approx. $1 \mathrm{ppm}$ downfield of resonances associated with the unsubstituted complexes $(X=H)$. The phosphorus resonances for the isothiocyanate complexes were found 2-4 ppm downfield from resonances corresponding to the azide complexes with the same ligand.

Selected FTIR data of the isothiocyanate and azide complexes are listed in Table 1. In general, $\mathrm{CN}$ stretching or $\mathrm{N}_{3}$ asymmetric stretching frequency decreases when changing the phosphorus substituents from ${ }^{\mathrm{t}} \mathrm{Bu}$ to ${ }^{\mathrm{i}} \mathrm{Pr}$ and from ${ }^{\mathrm{i}} \mathrm{Pr}$ to $\mathrm{Ph}$ (e.g., $2 \mathbf{a a}>$ $\mathbf{2 a b}>\mathbf{2 a c}$ for $\boldsymbol{v}_{\mathrm{CN}}$ ). The only exception is $\mathbf{3 b c}$ which has a slightly higher $\boldsymbol{v}_{\mathrm{N} 3}$ value than 3bb. Introducing an electron-withdrawing ester group at the para position of the ipso carbon results in lower values in $v_{\mathrm{CN}}$ for the ${ }^{\mathrm{t}} \mathrm{Bu}$ and ${ }^{\mathrm{i}} \mathrm{Pr}$-substituted isothiocyanate complexes (2aa vs. 2ba, 2ab vs. 2bb,) as well as $v_{\mathrm{N} 3}$ for the ${ }^{\mathrm{i}}$ Pr-substituted azide complexes (3ab vs. 3bb), but has almost no influence on the remaining pairs (2ac vs. 2bc, 3aa vs. 3ba, or 3ac vs. 3bc).

\section{Table 1}

$\mathrm{CN}$ stretching or $\mathrm{N}_{3}$ asymmetric stretching frequencies of [4-Z-2,6- $\left.\left(\mathrm{R}_{2} \mathrm{PO}\right)_{2} \mathrm{C}_{6} \mathrm{H}_{2}\right] \mathrm{NiX}$ complexes $\left(\mathrm{cm}^{-1}\right)$

\begin{tabular}{lllllll}
\hline & \multicolumn{3}{l}{ Isothiocyanate complexes $(\mathrm{X}=\underline{\mathrm{NCS}})$} & \multicolumn{3}{l}{ Azide complexes $\left(\mathrm{X}=\mathrm{N}_{3}\right)$} \\
\cline { 2 - 7 } & $\mathrm{R}={ }^{\mathrm{t}} \mathrm{Bu}$ & $\mathrm{R}={ }^{\mathrm{i}} \mathrm{Pr}$ & $\mathrm{R}=\mathrm{Ph}$ & $\mathrm{R}={ }^{\mathrm{t}} \mathrm{Bu}$ & $\mathrm{R}={ }^{\mathrm{i}} \mathrm{Pr}$ & $\mathrm{R}=\mathrm{Ph}$ \\
\hline $\mathrm{Z}=\mathrm{H}$ & $2104(\mathbf{2 a a})$ & $2091(\mathbf{2 a b})$ & $2072(\mathbf{2 a c})$ & $2072(\mathbf{3 a a})$ & $2053(\mathbf{3 a b})$ & $2048(\mathbf{3 a c})$ \\
$\mathrm{Z}=\mathrm{CO}_{2} \mathrm{Me}$ & $2098(\mathbf{2 b a})$ & $2082(\mathbf{2 b b})$ & $2071(\mathbf{2 b c})$ & $2073(\mathbf{3 b a})$ & $2047(\mathbf{3 b b})$ & $2049(\mathbf{3 b c})$ \\
\hline
\end{tabular}

The nickel isothiocyanate and azide complexes described in this work crystallized readily and were conveniently studied by X-ray crystallography. As representative examples, structures of 2aa, 2bb, 3ac and 3ba are shown in Figures 1-4, respectively. The structure of 3ab has been previously reported by Zargarian and co-workers [7m]. Structures and crystallographic data of the remaining seven complexes (2ab, $\mathbf{2} \mathbf{a c}, \mathbf{2} \mathbf{b a}$, $\mathbf{2 b c}, \mathbf{3 a a}, \mathbf{3 b b}$ and $\mathbf{3 b c}$ ) are provided in the Supplementary data (Appendix B). For comparison purposes, $\mathrm{Ni}-\mathrm{C}_{\mathrm{ipso}}$ and $\mathrm{Ni}-\mathrm{N}$ bond lengths of these complexes are 
summarized in Tables 2 and 3, respectively, while the $\mathrm{Ni}-\mathrm{N}-\mathrm{C}$ and $\mathrm{Ni}-\mathrm{N}-\mathrm{N}$ bond angles are listed in Table 4.

As shown in Table 2, the Ni- $\mathrm{C}_{\mathrm{ipso}}$ bond length is essentially constant for both isothiocyanate and azide complexes (1.88-1.89 $\AA$ ), and unaffected by the substituents on the phosphorus donors or at the para position of the aromatic pincer backbone. Similar results were observed in POCOP-pincer nickel thiolate complexes [9]. The $\mathrm{Ni}-\mathrm{N}$ bond lengths for the isothiocyanate complexes (1.86-1.87 $\AA$ ) are slightly shorter than those for the azide complexes (1.90-1.94 $\AA$ ); however the Ni-N bond lengths for the unsubstituted azide complexes (1.91-1.94 $\AA$ ) and those adorned by an ester group (1.90-1.92A) in the para position of the aromatic pincer ligand are unchanged. In the nickel isothiocyanate complexes, the NCS ligand maintains its linear geometry (N-C-S bond angle: 178.7-179.7 , see Appendix B. Supplementary data) and deviates slightly from the $\mathrm{C}_{\mathrm{ipso}}-\mathrm{Ni}-\mathrm{N}$ vector in the coordination plane with a $\mathrm{Ni}-\mathrm{N}-\mathrm{C}$ bond angle of $160.5-178.7^{\circ}$ (Table 4). In contrast, the $\mathrm{N}_{3}$ ligand in the nickel azide complexes bends slightly from its original linear geometry $(\mathrm{N}-\mathrm{N}-\mathrm{N}$ bond angle: 175.1-176.2 ${ }^{\circ}$, see Appendix B. Supplementary data) and deviates significantly from the $\mathrm{C}_{\mathrm{ipso}}-\mathrm{Ni}-\mathrm{N}$ vector with a $\mathrm{Ni}-\mathrm{N}-\mathrm{N}$ bond angle of $127.6-139.0^{\circ}$. Similar bending is observed in other metal azide complexes $[7 \mathrm{~m}, 11,12]$. Of all the nickel complexes reported here, 2aa is the most symmetrical molecule in the solid state (Fig. 5). The linear NCS ligand ( $\mathrm{N}-\mathrm{C}-\mathrm{S}$ bond angle: $\left.179.7(2)^{\circ}\right)$ is within the coordination plane and essentially extended from the $\mathrm{C}_{\mathrm{ipso}}-\mathrm{Ni}-\mathrm{N}$ vector $\left(\mathrm{Ni}-\mathrm{N}-\mathrm{C}\right.$ bond angle: $\left.178.7(2)^{\circ}\right)$. The NCS ligand of other isothiocyanate complexes is bent with respect to the $\mathrm{C}_{\mathrm{ipso}}-\mathrm{Ni}-\mathrm{N}$ vector, likely influenced by the varying conformations of the $\mathrm{R}$ groups bound to phosphorus and/or asymmetry induced by the ester group. Nevertheless, in solution, the rotation of the Ni-N bonds are not restricted as all ${ }^{31} \mathrm{P}\left\{{ }^{1} \mathrm{H}\right\}$ NMR spectra display a singlet resonance. 


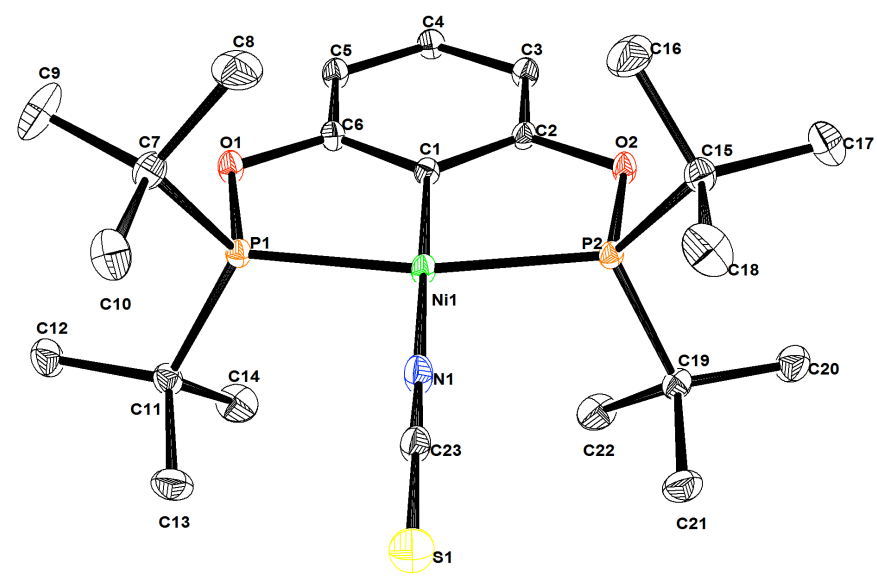

Fig. 1 ORTEP drawing of $\left[2,6-\left({ }^{\mathrm{t}} \mathrm{Bu}_{2} \mathrm{PO}\right){ }_{2} \mathrm{C}_{6} \mathrm{H}_{3}\right] \mathrm{Ni}(\mathrm{NCS})(\mathbf{2 a a})$ at the $50 \%$ probability level. Hydrogen atoms are omitted for clarity. Selected bond length $(\AA)$ and angles $\left({ }^{\circ}\right): \mathrm{Ni1}-\mathrm{N} 1=1.8643(18), \mathrm{Ni1}-\mathrm{C} 1=1.8787(19), \mathrm{Ni1}-\mathrm{P} 1=2.1827(6)$, Ni1-P2 = $2.1927(6), \mathrm{N} 1-\mathrm{C} 23=1.167(3) ; \mathrm{C} 23-\mathrm{S} 1=1.625(2) ; \mathrm{P} 1-\mathrm{Ni} 1-\mathrm{P} 2=164.51(2)$, $\mathrm{P} 1-\mathrm{Ni} 1-\mathrm{N} 1=97.51(6), \mathrm{P} 2-\mathrm{Ni} 1-\mathrm{N} 1=97.97(6), \mathrm{C} 1-\mathrm{Ni} 1-\mathrm{N} 1=179.13(9)$, $\mathrm{C} 23-\mathrm{N} 1-\mathrm{Ni1}=178.7(2), \mathrm{N} 1-\mathrm{C} 23-\mathrm{S} 1=179.7(2)$.

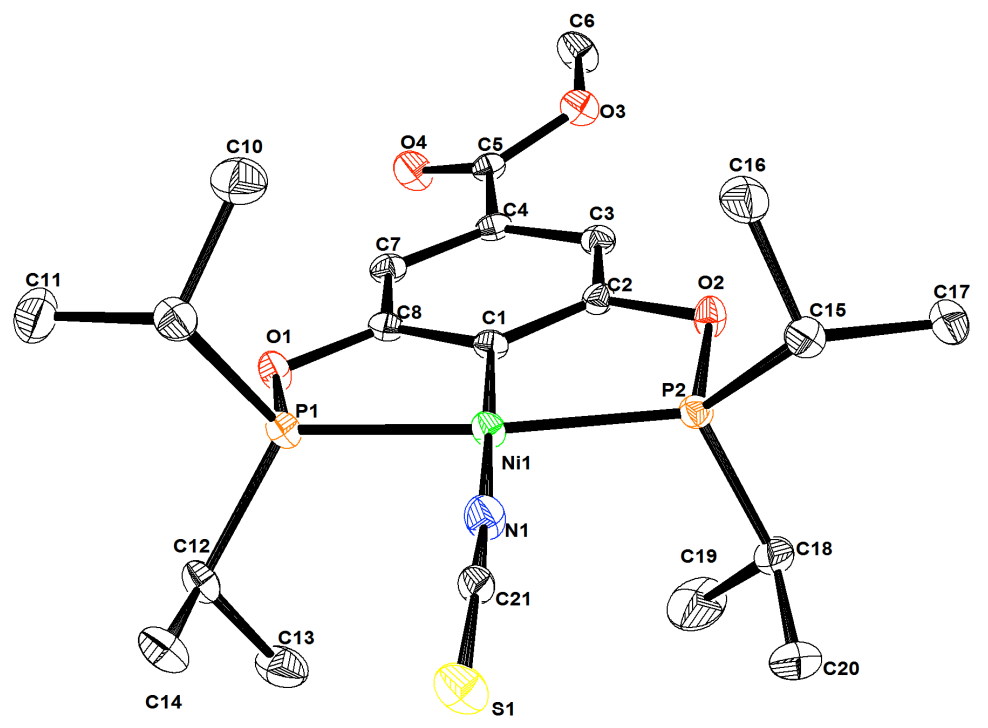

Fig. 2 ORTEP drawing of [4- $\left.\mathrm{CO}_{2} \mathrm{Me}-2,6-\left({ }^{\mathrm{i}} \mathrm{Pr}_{2} \mathrm{PO}\right)_{2} \mathrm{C}_{6} \mathrm{H}_{2}\right] \mathrm{Ni}(\mathrm{NCS})(\mathbf{2 b b})$ at the $50 \%$ probability level. Hydrogen atoms are omitted for clarity. Selected bond length $(\AA)$ and angles $\left({ }^{\circ}\right)$ : Ni1-N1 $=1.867(3)$, Ni1-C1 = 1.886(3), Ni1-P1 = 2.1679(10), $\mathrm{Ni1}-\mathrm{P} 2=2.1680(10), \mathrm{N} 1-\mathrm{C} 21=1.169(4) ; \mathrm{C} 21-\mathrm{S} 1=1.629(3) ; \mathrm{P} 1-\mathrm{Ni1}-\mathrm{P} 2=$ 163.61(3), $\mathrm{P} 1-\mathrm{Ni} 1-\mathrm{N} 1=97.82(10), \mathrm{P} 2-\mathrm{Ni1}-\mathrm{N} 1=98.29(10), \mathrm{C} 1-\mathrm{Ni} 1-\mathrm{N} 1=$ 178.09(13), C21-N1-Ni1 = 175.4(3), N1-C21-S1 = 179.0(3). 


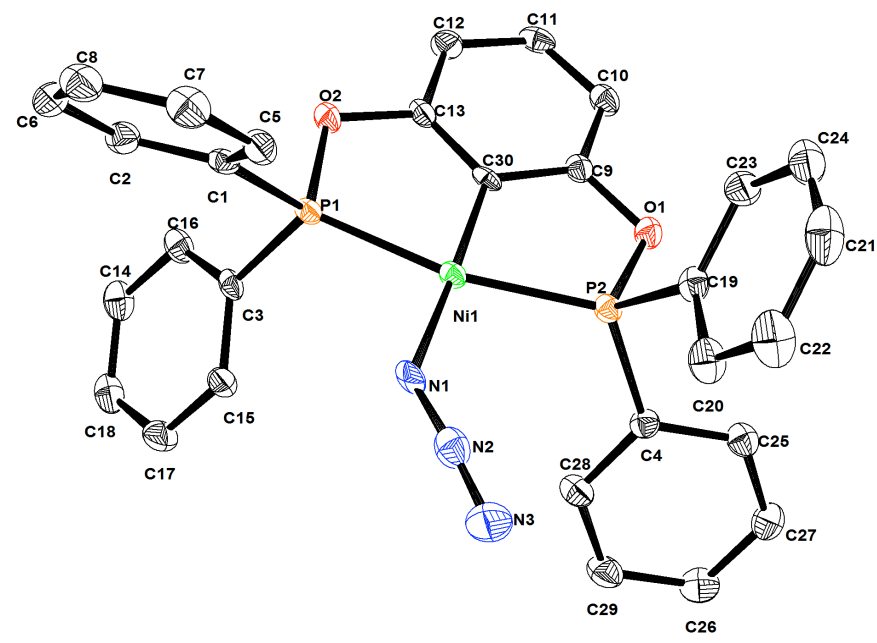

Fig. 3 ORTEP drawing of $\left[2,6-\left(\mathrm{Ph}_{2} \mathrm{PO}\right)_{2} \mathrm{C}_{6} \mathrm{H}_{3}\right] \mathrm{NiN}_{3}$ (3ac) at the $50 \%$ probability level. Hydrogen atoms are omitted for clarity. Selected bond length $(\AA)$ and angles $\left({ }^{\circ}\right): \mathrm{Ni} 1-\mathrm{N} 1=1.934(2), \mathrm{Ni1}-\mathrm{C} 30=1.880(3), \mathrm{Ni1}-\mathrm{P} 1=2.1760(9), \mathrm{Ni1}-\mathrm{P} 2=$ 2.1587(8), $\mathrm{N} 1-\mathrm{N} 2=1.153(3) ; \mathrm{N} 2-\mathrm{N} 3=1.157(4) ; \mathrm{P} 1-\mathrm{N} 11-\mathrm{P} 2=162.95(3)$, $\mathrm{P} 1-\mathrm{Ni} 1-\mathrm{N} 1=96.92(7), \mathrm{P} 2-\mathrm{Ni} 1-\mathrm{N} 1=100.04(7), \mathrm{C} 30-\mathrm{Ni} 1-\mathrm{N} 1=177.57(12)$, $\mathrm{N} 2-\mathrm{N} 1-\mathrm{Ni1}=133.7(2), \mathrm{N} 1-\mathrm{N} 2-\mathrm{N} 3=175.4(3)$.

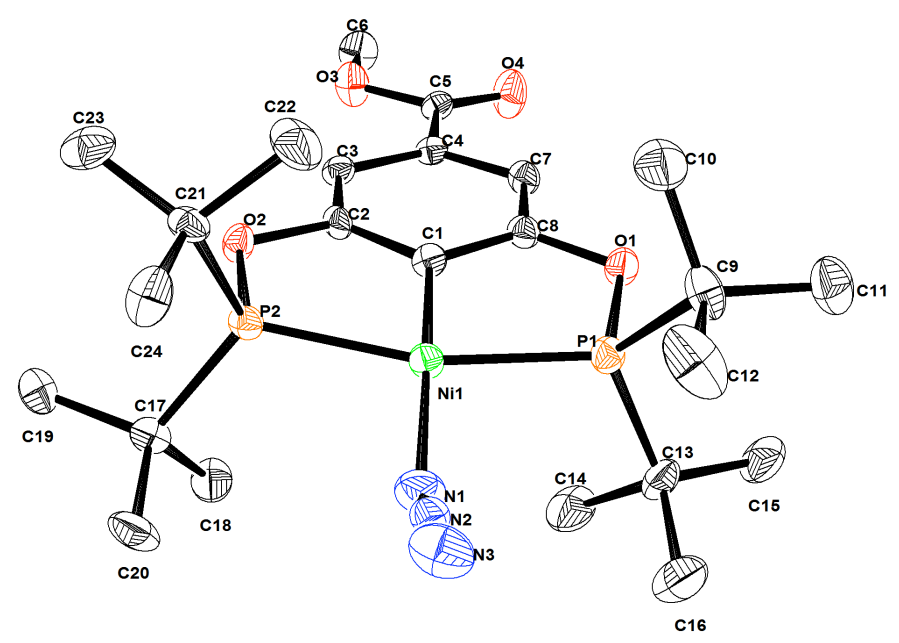

Fig. 4 ORTEP drawing of $\left[4-\mathrm{CO}_{2} \mathrm{Me}-2,6-\left({ }^{\mathrm{t}} \mathrm{Bu}{ }_{2} \mathrm{PO}\right)_{2} \mathrm{C}_{6} \mathrm{H}_{2}\right] \mathrm{NiN}_{3}$ (3ba) at the $50 \%$ probability level. Hydrogen atoms are omitted for clarity. Selected bond length $(\AA)$ and angles $\left(^{\circ}\right)$ : Ni1-N1 $=1.900(6), \mathrm{Ni1}-\mathrm{C} 1=1.884(6), \mathrm{Ni1}-\mathrm{P} 1=2.1837(15)$, $\mathrm{Ni1}-\mathrm{P} 2=2.1884(16), \mathrm{N} 1-\mathrm{N} 2=1.180(7) ; \mathrm{N} 2-\mathrm{N} 3=1.159(7) ; \mathrm{P} 1-\mathrm{Ni} 1-\mathrm{P} 2=$ 163.49(7), P1-Ni1-N1 = 98.16(17), P2-Ni1-N1 = 98.28(17), C1-Ni1-N1 = 169.9(2), $\mathrm{N} 2-\mathrm{N} 1-\mathrm{Ni1}=138.3(5), \mathrm{N} 1-\mathrm{N} 2-\mathrm{N} 3=175.3(6)$. 


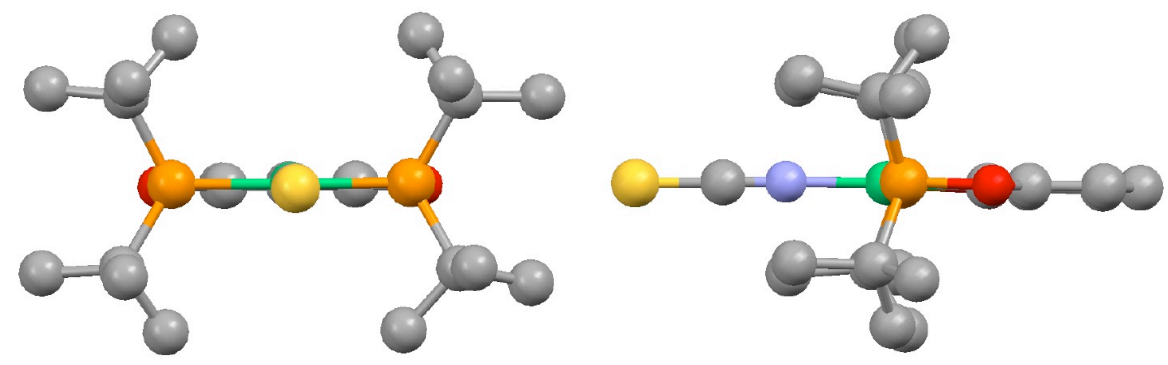

Fig. 5 Side views of $\mathbf{2 a a}$ illustrating the symmetrical geometry

\section{Table 2}

$\mathrm{Ni}-\mathrm{C}_{\text {ipso }}$ bond lengths $(\AA)$ of nickel isothiocyanate and azide complexes $\left[4-\mathrm{Z}-2,6-\left(\mathrm{R}_{2} \mathrm{PO}\right)_{2} \mathrm{C}_{6} \mathrm{H}_{2}\right] \mathrm{NiX}$

\begin{tabular}{lllllll}
\hline & \multicolumn{5}{l}{ Isothiocyanate complexes $(\mathrm{X}=\underline{\mathrm{NCS}})$} & \multicolumn{4}{l}{ Azide complexes $\left(\mathrm{X}=\mathrm{N}_{3}\right)$} \\
\cline { 2 - 7 } & $\mathrm{R}={ }^{\mathrm{B}} \mathrm{Bu}$ & $\mathrm{R}={ }^{\mathrm{i}} \mathrm{Pr}$ & $\mathrm{R}=\mathrm{Ph}$ & $\mathrm{R}={ }^{\mathrm{B} u}$ & $\mathrm{R}={ }^{\mathrm{i}} \mathrm{Pr}$ & $\mathrm{R}=\mathrm{Ph}$ \\
\hline $\mathrm{Z}=\mathrm{H}$ & $1.8787(19)(\mathbf{2 a a})$ & $1.8854(11)(\mathbf{2 a b})$ & $1.889(2)(\mathbf{2 a c})$ & $1.884(3)(\mathbf{3 a a})$ & $1.891(3)(\mathbf{3 a b})^{a}$ & $1.880(3)(3 \mathbf{a c})$ \\
$\mathrm{Z}=\mathrm{CO}_{2} \mathrm{Me}$ & $1.8765(17)(\mathbf{2 b a})$ & $1.886(3)(\mathbf{2 b b})$ & $1.8760(18)(\mathbf{2 b c})$ & $1.884(6)(\mathbf{3 b a})$ & $1.8775(14)(\mathbf{3 b b})$ & $1.8866(18)(3 \mathbf{b c})$ \\
\hline
\end{tabular}

${ }^{a}$ Data obtained from the cif file of Ref. $7 \mathrm{~m}$.

Table $3 \mathrm{Ni}-\mathrm{N}$ bond lengths $(\AA)$ of nickel isothiocyanate and azide complexes $\left[4-\mathrm{Z}-2,6-\left(\mathrm{R}_{2} \mathrm{PO}\right)_{2} \mathrm{C}_{6} \mathrm{H}_{2}\right] \mathrm{NiX}$

\begin{tabular}{lllllll}
\hline & \multicolumn{5}{l}{ Isothiocyanate complexes $(\mathrm{X}=\underline{\mathrm{NCS}})$} & \multicolumn{3}{l}{ Azide complexes $\left(\mathrm{X}=\mathrm{N}_{3}\right)$} \\
\cline { 2 - 6 } & $\mathrm{R}={ }^{\mathrm{t}} \mathrm{Bu}$ & $\mathrm{R}={ }^{\mathrm{i}} \mathrm{Pr}$ & $\mathrm{R}=\mathrm{Ph}$ & $\mathrm{R}={ }^{\mathrm{t}} \mathrm{Bu}$ & $\mathrm{R}={ }^{\mathrm{i}} \mathrm{Pr}$ & $\mathrm{R}=\mathrm{Ph}$ \\
\hline $\mathrm{Z}=\mathrm{H}$ & $1.8643(18)(\mathbf{2 a a})$ & $1.8715(10)(\mathbf{2 a b})$ & $1.8739(18)(\mathbf{2 a c})$ & $1.914(3)(\mathbf{3 a a})^{a}$ & $1.935(2)(\mathbf{3 a b})^{b}$ & $1.934(2)(\mathbf{3 a c})$ \\
& & & & $1.936(14)$ & & \\
$\mathrm{Z}=\mathrm{CO}_{2} \mathrm{Me}$ & $1.8667(16)(\mathbf{2 b a})$ & $1.867(3)(\mathbf{2 b b})$ & $1.8714(17)(\mathbf{2 b c})$ & $1.900(6)(\mathbf{3 b a})$ & $1.9174(14)(\mathbf{3 b b})$ & $1.9036(16)(\mathbf{3 b c})$ \\
\hline
\end{tabular}

${ }^{a}$ The N-atoms of the $\mathrm{N}_{3}$ group in complex 3aa are disordered, both Ni1-N1 and Ni1-N1A bond lengths are listed. ${ }^{b}$ Data obtained from the cif file of Ref. $7 \mathrm{~m}$.

\section{Table 4}

$\mathrm{Ni}-\mathrm{N}-\mathrm{C}$ bond angles $\left(^{\circ}\right)$ of $\left[4-\mathrm{Z}-2,6-\left(\mathrm{R}_{2} \mathrm{PO}\right)_{2} \mathrm{C}_{6} \mathrm{H}_{2}\right] \mathrm{Ni}(\underline{\mathrm{NCS}})$ and $\mathrm{Ni}-\mathrm{N}-\mathrm{N}$ bond angles $\left.{ }^{\circ}\right)$ of $\left[4-\mathrm{Z}-2,6-\left(\mathrm{R}_{2} \mathrm{PO}\right)_{2} \mathrm{C}_{6} \mathrm{H}_{2}\right] \mathrm{NiN}_{3}$

\begin{tabular}{lllllll}
\hline & \multicolumn{5}{l}{ Isothiocyanate complexes $(\mathrm{X}=\underline{\mathrm{NCS}})$} & \multicolumn{3}{l}{ Azide complexes $\left(\mathrm{X}=\mathrm{N}_{3}\right)$} \\
\cline { 2 - 6 } & $\mathrm{R}={ }^{\mathrm{t}} \mathrm{Bu}$ & $\mathrm{R}={ }^{\mathrm{i}} \mathrm{Pr}$ & $\mathrm{R}=\mathrm{Ph}$ & $\mathrm{R}={ }^{\mathrm{t}} \mathrm{Bu}$ & $\mathrm{R}={ }^{\mathrm{i}} \mathrm{Pr}$ & $\mathrm{R}=\mathrm{Ph}$ \\
\hline $\mathrm{Z}=\mathrm{H}$ & $178.7(2)(\mathbf{2 a a})$ & $167.13(12)(\mathbf{2 a b})$ & $164.11(18)(\mathbf{2 a c})$ & $139.0(7)(\mathbf{3 a a})^{a}$ & $130.2(2)(\mathbf{3 a b})^{b}$ & $133.7(2)(\mathbf{3 a c})$ \\
& & & & $132 .(5)$ & & \\
$\mathrm{Z}=\mathrm{CO}_{2} \mathrm{Me}$ & $170.39(18)(\mathbf{2 b a})$ & $175.4(3)(\mathbf{2 b b})$ & $160.51(16)(\mathbf{2 b c})$ & $138.3(5)(\mathbf{3 b a})$ & $127.60(11)(\mathbf{3 b b})$ & $133.21(14)(\mathbf{3 b c})$ \\
\hline
\end{tabular}

${ }^{a}$ The $\mathrm{N}$-atoms of the $\mathrm{N}_{3}$ group in complex 3aa are disordered, both Ni1-N1-N2 and Ni1-N1A-N2A bond angles are listed. ${ }^{b}$ Data obtained from the cif file of Ref. $7 \mathrm{~m}$. 
Metathesis reaction of [4-Z-2,6- $\left.\left(\mathrm{R}_{2} \mathrm{PO}\right)_{2} \mathrm{C}_{6} \mathrm{H}_{2}\right] \mathrm{NiCl}$

Although the salt metathesis reactions between POCOP-pincer nickel chloride complexes and potassium thiocyanate or sodium azide all ultimately lead to the nickel isothiocyanate or azide complexes quantitatively, it would be useful to understand the reactivity differences of the pincer complexes. In particular, we were interested in knowing how the substituents on the phosphorus donors and the pincer aromatic backbone would influence the rates of the metathesis reactions. Given the fact that $\mathrm{NCS}^{-}$and $\mathrm{N}_{3}^{-}$both are linear species and in this case coordinate to nickel via nitrogen, we were curious as to whether there is a rate difference upon complexation using the starting chloro complex (refer to Scheme 1). Unfortunately, the poor solubility of potassium thiocyanate and sodium azide in most organic solvents and the relatively fast reaction rates for this type of reactions make it difficult to obtain reliable kinetic data. Using $\mathrm{Bu}_{4} \mathrm{NSCN}$ and $\mathrm{Bu}_{4} \mathrm{NN}_{3}$ would solve the solubility problem; however, with the exception of $\mathbf{1} \mathbf{a a}$ and $\mathbf{1 b a}$, the salt metathesis reactions are too fast (complete in one min at $0{ }^{\circ} \mathrm{C}$ ) to tell the difference among the nickel pincer complexes. As an alternative method, the salt metathesis reactions using $\mathrm{KSCN}$ and $\mathrm{NaN}_{3}$ (eq 2) were stopped after a short period of time and the reaction mixtures were analyzed by ${ }^{31} \mathrm{P}\left\{{ }^{1} \mathrm{H}\right\}$ NMR spectroscopy. In a typical experiment, a dilute THF solution of [4-Z-2,6-( $\left.\left.\mathrm{R}_{2} \mathrm{PO}\right)_{2} \mathrm{C}_{6} \mathrm{H}_{2}\right] \mathrm{NiCl}(0.1 \mathrm{mmol}$ in $3 \mathrm{~mL}$ of THF $)$ was mixed with a saturated THF solution of potassium thiocyanate or sodium azide $\left(0.1 \mathrm{mmol} \mathrm{KSCN}\right.$ or $\mathrm{NaN}_{3}$ mixed with $3 \mathrm{~mL}$ of THF) at $0^{\circ} \mathrm{C}$. The resulting mixture was stirred at $0^{\circ} \mathrm{C}$ for $5 \mathrm{~min}$ and then quickly quenched by adding $15 \mathrm{~mL}$ of water. This procedure resulted in precipitation of nickel pincer complexes while keeping $\mathrm{KSCN}$ and $\mathrm{NaN}_{3}$ in solution. The ratios between $\left[4-\mathrm{Z}-2,6-\left(\mathrm{R}_{2} \mathrm{PO}\right)_{2} \mathrm{C}_{6} \mathrm{H}_{2}\right] \mathrm{NiCl}$ and $\left[4-\mathrm{Z}-2,6-\left(\mathrm{R}_{2} \mathrm{PO}\right)_{2} \mathrm{C}_{6} \mathrm{H}_{2}\right] \mathrm{NiX}(\mathrm{X}=$ NCS, $\mathrm{N}_{3}$ ) were determined by ${ }^{31} \mathrm{P}\left\{{ }^{1} \mathrm{H}\right\}$ NMR integrations, from which the conversions were calculated [13]. Table 5 summarizes the results for eight different reactions with six of them involving $\mathrm{NCS}^{-}$. Because of the poor solubility of KSCN and $\mathrm{NaN}_{3}$, their concentrations are constant throughout the reactions, and low enough to slow down the reactions so that reactivity difference between the nickel complexes could be observed. It should be noted that all the nickel complexes involved in this 
study tolerate water. No pincer species other than the starting nickel chloride complexes and the resulting nickel isothiocyanate or azide complexes was detected by ${ }^{31} \mathrm{P}\left\{{ }^{1} \mathrm{H}\right\}$ NMR. The low concentrations $(0.017 \mathrm{M}$ each) of the staring nickel chloride complexes and $\mathrm{KSCN}$ or $\mathrm{NaN}_{3}$ made the salt metathesis reactions slow enough that the conversions could be measured with accuracy within the same period of time (5 $\min )$.

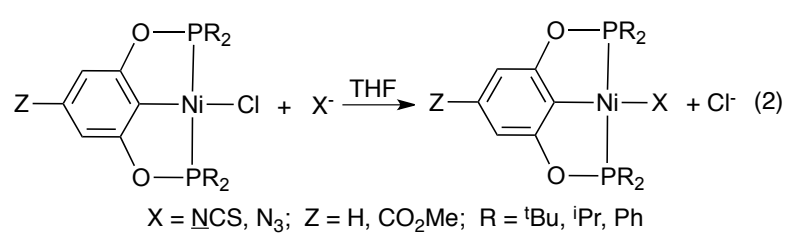

\section{Table 5}

Conversions of $\left[4-\mathrm{Z}-2,6-\left(\mathrm{R}_{2} \mathrm{PO}\right)_{2} \mathrm{C}_{6} \mathrm{H}_{2}\right] \mathrm{NiCl}$ to $\left[4-\mathrm{Z}-2,6-\left(\mathrm{R}_{2} \mathrm{PO}\right)_{2} \mathrm{C}_{6} \mathrm{H}_{2}\right] \mathrm{NiX}$ after $5 \mathrm{~min}$ at $0{ }^{\circ} \mathrm{C}$

\begin{tabular}{|c|c|c|c|c|c|}
\hline Entry & $\mathrm{Z}$ & $\mathrm{R}$ & $\mathrm{X}$ & Reactions & Conversion $(\%)$ \\
\hline 1 & $\mathrm{H}$ & ${ }^{\mathrm{t}} \mathrm{Bu}$ & NCS & $\mathbf{1 a a}+\mathrm{NCS}^{-} \rightarrow \mathbf{2 a a}+\mathrm{Cl}^{-}$ & 10 \\
\hline 2 & $\mathrm{H}$ & ${ }^{\mathrm{i}} \operatorname{Pr}$ & NCS & $\mathbf{1} \mathbf{a b}+\mathrm{NCS}^{-} \rightarrow \mathbf{2} \mathbf{a b}+\mathrm{Cl}^{-}$ & 76 \\
\hline 3 & $\mathrm{H}$ & $\mathrm{Ph}$ & $\underline{\mathrm{N} C S}$ & $\mathbf{1 a c}+\mathrm{NCS}^{-} \rightarrow \mathbf{2 a c}+\mathrm{Cl}^{-}$ & 83 \\
\hline 4 & $\mathrm{CO}_{2} \mathrm{Me}$ & ${ }^{\mathrm{t}} \mathrm{Bu}$ & NCS & $\mathbf{1 b a}+\mathrm{NCS}^{-} \rightarrow \mathbf{2 b a}+\mathrm{Cl}^{-}$ & 18 \\
\hline 5 & $\mathrm{CO}_{2} \mathrm{Me}$ & ${ }^{\mathrm{i}} \operatorname{Pr}$ & $\underline{\mathrm{NCS}}$ & $\mathbf{1 b b}+\mathrm{NCS}^{-} \rightarrow \mathbf{2} \mathbf{b b}+\mathrm{Cl}^{-}$ & 82 \\
\hline 6 & $\mathrm{CO}_{2} \mathrm{Me}$ & $\mathrm{Ph}$ & NCS & $\mathbf{1 b c}+\mathrm{NCS}^{-} \rightarrow \mathbf{2 b c}+\mathrm{Cl}^{-}$ & 87 \\
\hline 7 & $\mathrm{H}$ & ${ }^{\mathrm{i}} \operatorname{Pr}$ & $\mathrm{N}_{3}$ & $\mathbf{1} \mathbf{a b}+\mathrm{N}_{3}^{-} \rightarrow \mathbf{3 a b}+\mathrm{Cl}^{-}$ & 85 \\
\hline 8 & $\mathrm{CO}_{2} \mathrm{Me}$ & ${ }^{\mathrm{i}} \mathrm{Pr}$ & $\mathrm{N}_{3}$ & $\mathbf{1} \mathbf{b b}+\mathrm{N}_{3}^{-} \rightarrow \mathbf{3 b b}+\mathrm{Cl}^{-}$ & 91 \\
\hline
\end{tabular}

As shown in Table 5, for nickel chloride complexes bearing the same pincer backbone, those with phenyl groups as the phosphorus substituents are the most reactive complexes for the thiocyanate ion (entries 3 and 6), while those with tert-butyl groups on the phosphorus atoms are the least reactive ones (entries 1 and 4). Having an electron-withdrawing $\mathrm{CO}_{2} \mathrm{Me}$ group at the para position of the pincer backbone makes nickel complexes consistently more reactive (entry 1 vs. 4; entry 2 vs. 5; entry 3 vs. 6 ; entry 7 vs. 8), although the rate difference is small.

The relatively slow reactions for $\mathbf{1 a a}$ and $\mathbf{1 b a}$ are possibly due to sterics. Presumably, the metathesis or substitution reactions are associative or interchange-associative in nature, and the rates depend on how easily $\mathrm{SCN}^{-}$and $\mathrm{N}_{3}^{-}$ 
can approach the metal center. The bulky tert-butyl substituents are expected to be more sluggish. However, electronic effects can also play a role. Among the three different substituents used in this study $\left({ }^{\mathrm{t}} \mathrm{Bu},{ }^{\mathrm{i}} \mathrm{Pr}\right.$ and $\mathrm{Ph}$ ), the tert-butyl group is the most electron-donating substituent while the phenyl group is the least donating. The nickel center becomes more electron deficient going from 1aa to $\mathbf{1 a b}$ to $\mathbf{1 a c}$ or $\mathbf{1 b a}$ to $\mathbf{1 b b}$ to $\mathbf{1 b c}$, thus favoring the association of an incoming ligand. Furthermore, the introduction of an ester group to the para position of the pincer backbone accelerates the metathesis reactions, likely due to a more electron deficient metal center. As inferred from the crystal structures, the steric perturbation should be minimal.

\section{Isothiocyanate/azide exchange reactions}

In our previous study [9], nickel thiolate complexes were shown to undergo thiolate exchange between two different pincer units. Interestingly, similar ligand exchange between two different pincer ligated nickel centers was observed in the present study (eq 3). The reactions were clean with no other detectable species by ${ }^{31} \mathrm{P}\left\{{ }^{1} \mathrm{H}\right\}$ NMR except the four pincer complexes involved in each equilibrium. The equilibria were typically reached at room temperature in 2-3 d from either direction, or by mixing a random ratio of the four complexes. The equilibrium constants were conveniently measured by ${ }^{31} \mathrm{P}\left\{{ }^{1} \mathrm{H}\right\}$ NMR spectroscopy [13] as the complexes usually showed well-separated ${ }^{31} \mathrm{P}$ resonances. Table 6 summarizes the equilibrium constants, which were averaged from three individual experiments.

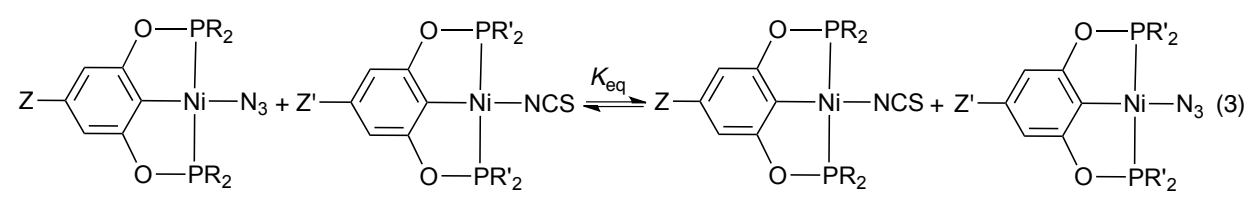


Table 6

Equilibrium constant for the isothiocyanate/azide exchange reactions $(\mathrm{T}=298 \mathrm{~K})$

\begin{tabular}{lllllll}
\hline Entry & $\mathrm{Z}$ & $\mathrm{Z}$ & $\mathrm{R}$ & $\mathrm{R}$ & Reactions & $K_{\mathrm{eq}}$ \\
\hline 1 & $\mathrm{H}$ & $\mathrm{CO}_{2} \mathrm{Me}$ & ${ }^{\mathrm{t}} \mathrm{Bu}$ & ${ }^{\mathrm{t}} \mathrm{Bu}$ & $\mathbf{3 a a}+\mathbf{2 b a}=\mathbf{2 a a}+\mathbf{3 b a}$ & $1.33 \pm 0.08$ \\
2 & $\mathrm{H}$ & $\mathrm{CO}_{2} \mathrm{Me}$ & ${ }^{\mathrm{i}} \mathrm{Pr}$ & ${ }^{\mathrm{i}} \mathrm{Pr}$ & $\mathbf{3 a b}+\mathbf{2 b b}=\mathbf{2 a b}+\mathbf{3 b b}$ & $1.45 \pm 0.02$ \\
3 & $\mathrm{H}$ & $\mathrm{CO}_{2} \mathrm{Me}$ & $\mathrm{Ph}$ & $\mathrm{Ph}$ & $\mathbf{3 a c}+\mathbf{2 b c}=\mathbf{2 a c}+\mathbf{3 b c}$ & $1.35 \pm 0.02$ \\
4 & $\mathrm{H}$ & $\mathrm{H}$ & ${ }^{\mathrm{t}} \mathrm{Bu}$ & ${ }^{\mathrm{i}} \mathrm{Pr}$ & $\mathbf{3 a a}+\mathbf{2 a b}=\mathbf{2 a a}+\mathbf{3 a b}$ & $3.53 \pm 0.08$ \\
5 & $\mathrm{H}$ & $\mathrm{H}$ & ${ }^{\mathrm{i}} \mathrm{Pr}$ & $\mathrm{Ph}$ & $\mathbf{3 a b}+\mathbf{2 a c}=\mathbf{2 a b}+\mathbf{3 a c}$ & $2.48 \pm 0.04$ \\
6 & $\mathrm{H}$ & $\mathrm{H}$ & ${ }^{\mathrm{t}} \mathrm{Bu}$ & $\mathrm{Ph}$ & $\mathbf{3 a a}+\mathbf{2 a c}=\mathbf{2 a a}+\mathbf{3 a c}$ & $8.4 \pm 0.7$ \\
7 & $\mathrm{CO}_{2} \mathrm{Me}$ & $\mathrm{CO}_{2} \mathrm{Me}$ & ${ }^{\mathrm{t}} \mathrm{Bu}$ & ${ }^{\mathrm{i}} \mathrm{Pr}$ & $\mathbf{3 b a}+\mathbf{2 b b}=\mathbf{2 b a}+\mathbf{3 b b}$ & $3.75 \pm 0.09$ \\
8 & $\mathrm{CO}_{2} \mathrm{Me}$ & $\mathrm{CO}_{2} \mathrm{Me}$ & ${ }^{\mathrm{i}} \mathrm{Pr}$ & $\mathrm{Ph}$ & $\mathbf{3 b b}+\mathbf{2 b c}=\mathbf{2 b b}+\mathbf{3 b c}$ & $2.5 \pm 0.2$ \\
9 & $\mathrm{CO}_{2} \mathrm{Me}$ & $\mathrm{CO}_{2} \mathrm{Me}$ & ${ }^{\mathrm{t}} \mathrm{Bu}$ & $\mathrm{Ph}$ & $\mathbf{3 b a}+\mathbf{2 b c}=\mathbf{2 b a}+\mathbf{3 b c}$ & $10.1 \pm 0.9$ \\
\hline
\end{tabular}

The first three equilibria (entries 1-3) involve the exchange of isothiocyanate and azide ligands between an ester-substituted nickel pincer unit and an unsubstituted one. The equilibrium constants are all greater than one, suggesting the azide ligand prefers the more electron-deficient nickel center. As previously mentioned, the electron "richness" of the nickel center follows a decreasing order of $\left\{\left[2,6-\left({ }^{\mathrm{t}} \mathrm{Bu}_{2} \mathrm{PO}\right)_{2} \mathrm{C}_{6} \mathrm{H}_{3}\right] \mathrm{Ni}\right\}^{+}>\left\{\left[2,6-\left({ }^{\mathrm{i}} \mathrm{Pr}_{2} \mathrm{PO}\right)_{2} \mathrm{C}_{6} \mathrm{H}_{3}\right] \mathrm{Ni}\right\}^{+}>\left\{\left[2,6-\left(\mathrm{Ph}_{2} \mathrm{PO}\right)_{2} \mathrm{C}_{6} \mathrm{H}_{3}\right] \mathrm{Ni}\right\}^{+}$. Therefore, altering the phosphorus substituents while keeping the same pincer backbone would establish an equilibrium in which the azide ligand binds preferentially to $\left\{\left[2,6-\left(\mathrm{Ph}_{2} \mathrm{PO}\right)_{2} \mathrm{C}_{6} \mathrm{H}_{3}\right] \mathrm{Ni}\right\}^{+}$(entries 5 and 6) followed by $\left\{\left[2,6-\left({ }^{\mathrm{i}} \mathrm{Pr}_{2} \mathrm{PO}\right)_{2} \mathrm{C}_{6} \mathrm{H}_{3}\right] \mathrm{Ni}\right\}^{+}$(entry 4). Similar results were obtained when the ester-substituted POCOP-pincer ligands were employed (entries 7-9).

\section{Quantum chemical analysis of the isothiocyanate and azide ions}

To gain a better understanding of the aforementioned metathesis and ligand exchange reactions, a quantum chemical analysis of isothiocyanate and azide ions was carried out focusing on the properties of the coordinating nitrogen atoms. The ground-state geometries were optimized by the second-order Møller-Plesset perturbation (MP2) method using the $6-311++\mathrm{G}(\mathrm{d}, \mathrm{p})$ basis set, and the charges were obtained from the NPA population analysis. The condensed values of local reactivity descriptors of the coordinating nitrogen atoms in $\mathrm{SCN}^{-}$and $\mathrm{N}_{3}^{-}$are listed in Table 7. 


\section{Table 7}

Condensed values of local reactivity descriptors of the coordinating nitrogen atoms in $\mathrm{SCN}^{-}$and $\mathrm{N}_{3}^{-}$

\begin{tabular}{lccccccc}
\hline & $f_{k}^{+}$ & $s^{+}$ & $f_{k}^{-}$ & $s^{-}$ & $f_{k}^{2}$ & $S / \mathrm{eV}^{-1}$ & $s_{k}{ }^{2} / \mathrm{meV}^{-1}$ \\
\hline $\mathrm{SCN}^{-}$ & 0.1691 & 0.0183 & 0.2616 & 0.0283 & -0.0925 & 0.1081 & -1.0809 \\
$\mathrm{~N}_{3}^{-}$ & 0.4514 & 0.0417 & 0.5147 & 0.0475 & -0.0633 & 0.0923 & -0.5393 \\
\hline
\end{tabular}

$f_{k}^{+}$and $f_{k}^{-}$: condensed Fukui function; $s^{+}$and $s^{-}$: local softness; $f_{k}^{2}:$ dual descriptor; $S$ : global softness; $s_{k}^{2}$ : local hypersoftness

The calculations indicate that with a larger condensed Fukui function $f_{k}^{-}$value and a larger local softness $s^{-}$value, the coordinating nitrogen atom in $\mathrm{N}_{3}^{-}$is more nucleophilic than that of $\mathrm{SCN}^{-}$[14]. However, the $\mathrm{SCN}^{-}$nitrogen has a larger global softness value $S$ and a more negative local hypersoftness $s_{k}^{2}$ value. This implies that the nitrogen end of $\mathrm{SCN}^{-}$is a softer base than the terminal nitrogen of $\mathrm{N}_{3}^{-}$.

Substituent effect on the electrophilicity of the nickel center of this type of complexes has been studied by Zargarian and co-workers using cyclic voltammetry [7f,h]. It was found that the oxidation potentials of this type of complexes are affected by both $\mathrm{P}$ - and ring-substituents. For complexes with the same aromatic pincer backbone, oxidation of the nickel center becomes more difficult when the P-substituent changes from ${ }^{t} \mathrm{Bu}$ to ${ }^{\mathrm{i}} \mathrm{Pr}$, or from ${ }^{\mathrm{i}} \mathrm{Pr}$ to $\mathrm{Ph}$. Oxidation is also more difficult for complexes containing an electron-withdrawing substituent at the para-position.

According to the hard-soft acid-base theory (HSAB theory), the acid/base interaction between two hard or two soft species are stronger and generally form a more stable complex than the interaction between one hard and one soft species. The calculations are consistent with the equilibrium constant measurements described in Table 6; the azide ligand, which is a harder base, prefers a less electron rich nickel center (i.e., a harder acid) whereas the isothiocyanate ligand, which is a softer base, prefers a more electron rich nickel center (i.e., a softer acid). 


\section{Conclusions}

A dozen new nickel isothiocyanate and azide complexes have been synthesized from bis(phosphinite) pincer ligated nickel chloride complexes and $\mathrm{KSCN} / \mathrm{NaN}_{3}$. In order to better understand how substituents influence the kinetic and thermodynamic behavior of these complexes, complexes were synthesized with varying substituents on the phosphorus donor atoms and pincer aromatic backbone. X-ray crystallographic studies show little change the $\mathrm{Ni}-\mathrm{N}$ and $\mathrm{Ni}-\mathrm{C}_{\text {ipso }}$ bond lengths of the resulting nickel pincer isothiocyanate and azide complexes by the P-substituents or aromatic pincer ring modification. However, substituent effects have been observed on the rates of the $\mathrm{Ni}-\mathrm{N}$ bond formation during the metathesis reactions of the nickel chloride complexes with $\mathrm{KSCN} / \mathrm{NaN}_{3}$, and on the strength of the $\mathrm{Ni}-\mathrm{N}$ bonds that influence the exchange of isothiocyanate and azide ligands on two different nickel pincer units. The metathesis reaction is faster with a less electron rich nickel center. Calculations have shown that the terminal nitrogen of $\mathrm{N}_{3}^{-}$is harder than the nitrogen end of $\mathrm{SCN}^{-}$, thus explaining why the azide ligand prefers a less electron rich nickel center while the isothiocyanate ligand prefers a more electron rich nickel center.

\section{Experimental section}

\section{General procedures}

Unless otherwise indicated, all the syntheses were carried out under a nitrogen atmosphere using standard Schlenk and glove box techniques. Solvents used for the reactions were degassed and dried using standard procedures. The pincer-ligated nickel chloride, isothiocyanate and azide complexes reported in this work, once isolated, can be handled in air without noticeable decomposition. $\left[2,6-\left({ }^{\mathrm{t}} \mathrm{Bu}_{2} \mathrm{PO}\right)_{2} \mathrm{C}_{6} \mathrm{H}_{3}\right] \mathrm{NiCl} \quad(\mathbf{1 a a}) \quad[8 \mathrm{a}], \quad\left[2,6-\left({ }^{\mathrm{i}} \mathrm{Pr}_{2} \mathrm{PO}\right)_{2} \mathrm{C}_{6} \mathrm{H}_{3}\right] \mathrm{NiCl} \quad(\mathbf{1 a b}) \quad[6 \mathrm{c}]$ and $\left[2,6-\left(\mathrm{Ph}_{2} \mathrm{PO}\right)_{2} \mathrm{C}_{6} \mathrm{H}_{3}\right] \mathrm{NiCl}(\mathbf{1 a c})[6 \mathrm{~b}]$ were prepared as described in the literature. 
Synthesis of $\left[4-\mathrm{CO}_{2} \mathrm{Me}-2,6-\left({ }^{\mathrm{B}} \mathrm{Bu}{ }_{2} \mathrm{PO}\right)_{2} \mathrm{C}_{6} \mathrm{H}_{2}\right] \mathrm{NiCl}(\mathbf{l b a})$

To a solution of 3,5-dihydoxybenzoic acid methyl ester $(1.0 \mathrm{mmol})$ in $15 \mathrm{~mL}$ of THF was slowly added (via a syringe) a suspension of $\mathrm{NaH}(2.1 \mathrm{mmol})$ in $5 \mathrm{~mL}$ of THF (caution: hydrogen gas evolution). The resulting mixture was heated to reflux for $1 \mathrm{~h}$, followed by the addition (via a syringe) of a solution ${ }^{\mathrm{t}} \mathrm{Bu}_{2} \mathrm{PCl}(2.1 \mathrm{mmol})$ in $5 \mathrm{~mL}$ of THF, and then refluxed for an additional $1 \mathrm{~h}$. The solvent was evaporated under vacuum, and the residue was extracted with $40 \mathrm{~mL}$ of pentane. The pentane solution was concentrated under vacuum, first at room temperature and then at $55{ }^{\circ} \mathrm{C}$ for $2 \mathrm{~h}$ to remove the remaining ${ }^{t} \mathrm{Bu}_{2} \mathrm{PCl}$. The crude 3,5-( $\left.{ }^{\mathrm{t}} \mathrm{Bu}_{2} \mathrm{PO}\right)_{2} \mathrm{C}_{6} \mathrm{H}_{3} \mathrm{CO}_{2} \mathrm{Me}$ was obtained as a colorless viscous oil which occasionally solidified upon standing. This crude product was used in the next step without further purification and characterization.

Under a nitrogen atmosphere, the crude 3,5- $\left({ }^{\mathrm{t}} \mathrm{Bu}_{2} \mathrm{PO}\right)_{2} \mathrm{C}_{6} \mathrm{H}_{3} \mathrm{CO}_{2} \mathrm{Me}(1.38 \mathrm{~g}, 3.0$ mmol) was mixed with anhydrous $\mathrm{NiCl}_{2}(389 \mathrm{mg}, 3.0 \mathrm{mmol})$ in toluene $(50 \mathrm{~mL})$. The resulting mixture was refluxed under nitrogen for $18 \mathrm{~h}$, cooled to room temperature and filtered to remove the small amount of solid formed. The orange filtrate was concentrated under vacuum to $5 \mathrm{~mL}$, after which $30 \mathrm{~mL}$ of $\mathrm{Et}_{2} \mathrm{O}$ was added. The desired product formed as a precipitate, which was collected by filtration and washed with $\mathrm{Et}_{2} \mathrm{O}$. Complex $\mathbf{1 b a}$ was isolated as an orange-green powder (725 mg, 44\% yield). ${ }^{1} \mathrm{H}$ NMR (400 MHz, $\mathrm{CDCl}_{3}, \delta$ ): 7.06 (s, $\left.\mathrm{ArH}, 2 \mathrm{H}\right), 3.85$ (s, $\mathrm{OCH}_{3}$, $3 \mathrm{H}), 1.48\left(\mathrm{t}, J_{\mathrm{P}-\mathrm{H}}=6.8 \mathrm{~Hz}, \mathrm{C}\left(\mathrm{CH}_{3}\right)_{3}, 36 \mathrm{H}\right) .{ }^{13} \mathrm{C}\left\{{ }^{1} \mathrm{H}\right\} \mathrm{NMR}\left(101 \mathrm{MHz}, \mathrm{CDCl}_{3}, \delta\right)$ : $169.33\left(\mathrm{t}, J_{\mathrm{P}-\mathrm{C}}=9.1 \mathrm{~Hz}, \operatorname{ArC}\right), 167.15\left(\mathrm{~s}, \mathrm{CO}_{2} \mathrm{CH}_{3}\right), 133.86\left(\mathrm{t}, J_{\mathrm{P}-\mathrm{C}}=20.2 \mathrm{~Hz}, \mathrm{ArC}\right)$, $130.47(\mathrm{~s}, \mathrm{ArC}), 105.98\left(\mathrm{t}, J_{\mathrm{P}-\mathrm{C}}=6.1 \mathrm{~Hz}, \mathrm{ArC}\right), 52.12\left(\mathrm{~s}, \mathrm{CO}_{2} \mathrm{CH}_{3}\right), 39.58\left(\mathrm{t}, J_{\mathrm{P}-\mathrm{C}}=7.1\right.$ $\left.\mathrm{Hz}, \mathrm{C}\left(\mathrm{CH}_{3}\right)_{3}\right), 28.06\left(\mathrm{t}, J_{\mathrm{P}-\mathrm{C}}=2.8 \mathrm{~Hz}, \mathrm{C}\left(\mathrm{CH}_{3}\right)_{3}\right) .{ }^{31} \mathrm{P}\left\{{ }^{1} \mathrm{H}\right\} \mathrm{NMR}\left(162 \mathrm{MHz}, \mathrm{CDCl}_{3}, \delta\right)$ : 188.54 (s). Anal. Calcd for $\mathrm{C}_{24} \mathrm{H}_{41} \mathrm{O}_{4} \mathrm{P}_{2} \mathrm{ClNi}$ : C, 52.44; H, 7.52. Found: C, 52.61; H, 7.58 .

Synthesis of $\left[4-\mathrm{CO}_{2} \mathrm{Me}-2,6-\left({ }^{i} \mathrm{Pr}_{2} \mathrm{PO}\right)_{2} \mathrm{C}_{6} \mathrm{H}_{2}\right] \mathrm{NiCl}(\mathbf{l} \boldsymbol{b} \boldsymbol{b})$

To a Schlenk flask containing 3,5-dihydroxybenzoic acid methyl ester (840 mg, $5.0 \mathrm{mmol}$ ), anhydrous $\mathrm{NiCl}_{2}$ (972 $\left.\mathrm{mg}, 7.5 \mathrm{mmol}\right)$, and 4-dimethylaminopyridine (1.28 $\mathrm{g}, 10.5 \mathrm{mmol})$ in THF $(30 \mathrm{~mL})$ was added ${ }^{\mathrm{i}} \mathrm{Pr}_{2} \mathrm{PCl}(1.6 \mathrm{~mL}, 10.1 \mathrm{mmol})$ at room 
temperature. The mixture was stirred under a nitrogen atmosphere and heated to $80{ }^{\circ} \mathrm{C}$ for $18 \mathrm{~h}$. After cooling to room temperature, the volatiles were evaporated, and the resulting solid residue was extracted with $n$-hexane $(3 \times 20 \mathrm{~mL})$ and filtered. Slow evaporation of the combined solutions at ambient temperature produced $\mathbf{1 b b}$ as yellow-orange crystals $\left(2.05 \mathrm{~g}, 83 \%\right.$ yield). The ${ }^{1} \mathrm{H}$ NMR data are consistent with the literature values [10].

\section{Synthesis of $\left[4-\mathrm{CO}_{2} \mathrm{Me}-2,6-\left(\mathrm{Ph}_{2} \mathrm{PO}\right)_{2} \mathrm{C}_{6} \mathrm{H}_{2}\right] \mathrm{NiCl}(\mathbf{l b c})$}

To the mixture of 3,5-dihydroxybenzoic acid methyl ester ( $3.8 \mathrm{~g}, 23.0 \mathrm{mmol})$ and $\mathrm{Ph}_{2} \mathrm{PCl}(8.4 \mathrm{~mL}, 46.0 \mathrm{mmol})$ in toluene $(40 \mathrm{~mL})$ was added triethylamine $(7.0 \mathrm{~mL}$, $50.0 \mathrm{mmol}$ ) dropwise. The resulting mixture was heated to reflux for $18 \mathrm{~h}$. After cooling to room temperature, the volatiles were removed under vacuum and the residue was extracted with THF $(3 \times 20 \mathrm{~mL})$ and then filtered through a pad of Celite. After the removal of THF under vacuum, 3,5-( $\left.\mathrm{Ph}_{2} \mathrm{PO}\right)_{2} \mathrm{C}_{6} \mathrm{H}_{3} \mathrm{CO}_{2} \mathrm{Me}$ was isolated as a yellow-orange solid. This crude product was used in the next step without further purification and characterization.

Under a nitrogen atmosphere, the crude 3,5- $\left(\mathrm{Ph}_{2} \mathrm{PO}\right)_{2} \mathrm{C}_{6} \mathrm{H}_{3} \mathrm{CO}_{2} \mathrm{Me}(1.01 \mathrm{~g}, 1.89$ mmol) and $\mathrm{NiCl}_{2}(245 \mathrm{mg}, 1.89 \mathrm{mmol})$ were mixed with toluene $(50 \mathrm{~mL})$. The resulting mixture was refluxed for $24 \mathrm{~h}$. After cooling to room temperature, solvent was evaporated under vacuum and the residue was extracted with $\mathrm{CH}_{2} \mathrm{Cl}_{2}$. Removal of $\mathrm{CH}_{2} \mathrm{Cl}_{2}$ followed by recrystallization from diethyl ether produced $\mathbf{1 b c}$ as a yellow greenish crystalline solid (865 mg, 73\% yield). ${ }^{1} \mathrm{H}$ NMR (400 $\left.\mathrm{MHz}, \mathrm{CDCl}_{3}, \delta\right)$ : 7.94-8.02 (m, ArH, 8H), 7.44-7.56 (m, ArH, 12H), 7.28 (s, $\mathrm{ArH}, 2 \mathrm{H}), 3.87$ (s, $\mathrm{OCH}_{3}$, $3 \mathrm{H}) .{ }^{13} \mathrm{C}\left\{{ }^{1} \mathrm{H}\right\} \operatorname{NMR}\left(101 \mathrm{MHz}, \mathrm{CDCl}_{3}, \delta\right): 166.94\left(\mathrm{t}, J_{\mathrm{P}-\mathrm{C}}=12.1 \mathrm{~Hz}, \mathrm{ArC}\right), 166.69(\mathrm{~s}$, $\left.\mathrm{CO}_{2} \mathrm{CH}_{3}\right), 134.85\left(\mathrm{t}, J_{\mathrm{P}-\mathrm{C}}=23.2 \mathrm{~Hz}, \mathrm{ArC}\right), 132.14\left(\mathrm{t}, J_{\mathrm{P}-\mathrm{C}}=25.2 \mathrm{~Hz}, \mathrm{ArC}\right), 132.08(\mathrm{t}$, $\left.J_{\mathrm{P}-\mathrm{C}}=6.1 \mathrm{~Hz}, \operatorname{ArC}\right), 131.91\left(\mathrm{t}, J_{\mathrm{P}-\mathrm{C}}=7.1 \mathrm{~Hz}, \operatorname{ArC}\right), 131.84(\mathrm{~s}, \operatorname{ArC}), 128.99\left(\mathrm{t}, J_{\mathrm{P}-\mathrm{C}}=\right.$ $5.1 \mathrm{~Hz}, \operatorname{ArC}), 107.65\left(\mathrm{t}, J_{\mathrm{P}-\mathrm{C}}=7.1 \mathrm{~Hz} \mathrm{ArC}\right), 52.32\left(\mathrm{~s}, \mathrm{CO}_{2} C \mathrm{H}_{3}\right) .{ }^{31} \mathrm{P}\left\{{ }^{1} \mathrm{H}\right\} \mathrm{NMR}(162$ $\mathrm{MHz}, \mathrm{CDCl}_{3}, \delta$ ): 141.55 (s). Anal. Calcd for $\mathrm{C}_{32} \mathrm{H}_{25} \mathrm{O}_{4} \mathrm{P}_{2} \mathrm{ClNi}: \mathrm{C}, 61.04 ; \mathrm{H}$, 4.00. Found: C, 61.27; H, 4.18. 
Synthesis of $\left[2,6-\left(\mathrm{Bu}_{2} \mathrm{PO}\right)_{2} \mathrm{C}_{6} \mathrm{H}_{3}\right] \mathrm{Ni}(\underline{\mathrm{NCS}})(\mathbf{2 a a})$

A mixture of $\left[2,6-\left({ }^{\mathrm{t}} \mathrm{Bu}_{2} \mathrm{PO}\right)_{2} \mathrm{C}_{6} \mathrm{H}_{3}\right] \mathrm{NiCl}(\mathbf{1 a a})(492 \mathrm{mg}, 1.0 \mathrm{mmol})$ and $\mathrm{KSCN}$ (486 mg, $5.0 \mathrm{mmol})$ in THF $(20 \mathrm{~mL})$ was stirred in a sealed flask at room temperature for $5 \mathrm{~d}$. The volatiles were removed under vacuum and the residue was extracted with toluene and then filtered through a pad of Celite. Removal of toluene under vacuum produced 2 aa as an orange solid (452 mg, 88\% yield). ${ }^{1} \mathrm{H}$ NMR (400 $\mathrm{MHz}, \mathrm{CDCl}_{3}, \delta$ ): $6.94\left(\mathrm{t}, J_{\mathrm{H}-\mathrm{H}}=8.0 \mathrm{~Hz}, \operatorname{Ar} H, 1 \mathrm{H}\right), 6.41\left(\mathrm{~d}, J_{\mathrm{H}-\mathrm{H}}=8.0 \mathrm{~Hz}, \operatorname{Ar} H, 2 \mathrm{H}\right), 1.46\left(\mathrm{t}, J_{\mathrm{P}-\mathrm{H}}=7.6\right.$ $\left.\mathrm{Hz}, \mathrm{CH}_{3}, 36 \mathrm{H}\right) .{ }^{13} \mathrm{C}\left\{{ }^{1} \mathrm{H}\right\} \mathrm{NMR}\left(101 \mathrm{MHz}, \mathrm{CDCl}_{3}, \delta\right): 169.89$ (t, $\left.J_{\mathrm{P}-\mathrm{C}}=9.1 \mathrm{~Hz}, \mathrm{ArC}\right)$, $146.87(\mathrm{~s}, \mathrm{NCS}), 129.31(\mathrm{~s}, \operatorname{ArC}), 124.70\left(\mathrm{t}, J_{\mathrm{P}-\mathrm{C}}=20.0 \mathrm{~Hz}, \operatorname{ArC}\right), 105.42\left(\mathrm{t}, J_{\mathrm{P}-\mathrm{C}}=6.1\right.$ $\mathrm{Hz}, \mathrm{ArC}), 39.21\left(\mathrm{t}, J_{\mathrm{P}-\mathrm{C}}=7.5 \mathrm{~Hz}, C\left(\mathrm{CH}_{3}\right)_{3}\right), 27.88\left(\mathrm{t}, J_{\mathrm{P}-\mathrm{C}}=3.0 \mathrm{~Hz}, C \mathrm{H}_{3}\right) .{ }^{31} \mathrm{P}\left\{{ }^{1} \mathrm{H}\right\}$ NMR (162 MHz, $\left.\mathrm{CDCl}_{3}, \delta\right): 193.94$ (s). FTIR (KBr): $v_{\mathrm{CN}}=2104 \mathrm{~cm}^{-1}$. Anal. Calcd for $\mathrm{C}_{23} \mathrm{H}_{39} \mathrm{NO}_{2} \mathrm{P}_{2} \mathrm{SNi}$ C, 53.72; H, 7.64; N, 2.72. Found: C, 53.53; H, 7.54; N, 2.86.

Alternatively, a mixture of $\left[2,6-\left({ }^{\mathrm{t}} \mathrm{Bu}_{2} \mathrm{PO}\right)_{2} \mathrm{C}_{6} \mathrm{H}_{3}\right] \mathrm{NiCl}$ (1aa) $(492 \mathrm{mg}, 1 \mathrm{mmol})$ and KSCN (486 mg, $5 \mathrm{mmol})$ in THF $(20 \mathrm{~mL})$ was refluxed under an nitrogen atmosphere for $24 \mathrm{~h}$. After cooling to room temperature, the volatiles were removed under vacuum and the residue was extracted with toluene and then filtered through a pad of Celite. Removal of toluene under vacuum followed by recrystallization in $\mathrm{CH}_{2} \mathrm{Cl}_{2} /$ $n$-hexane produced 2aa as orange crystals (318 mg, $62 \%$ yield).

\section{Synthesis of $\left[2,6-\left({ }^{i} \mathrm{Pr}_{2} \mathrm{PO}\right)_{2} \mathrm{C}_{6} \mathrm{H}_{3}\right] \mathrm{Ni}(\underline{N C S})(\mathbf{2 a b})$}

Complex 2ab was prepared from $\mathbf{1 a b}$ and $\mathrm{KSCN}$ in $93 \%$ (room temperature) or $78 \%$ (under refluxing) yield by procedures similar to those used for $\mathbf{2 a a} .{ }^{1} \mathrm{H}$ NMR $\left(400 \mathrm{MHz}, \mathrm{CDCl}_{3}, \delta\right): 6.94\left(\mathrm{t}, J_{\mathrm{H}-\mathrm{H}}=8.0 \mathrm{~Hz}, \mathrm{Ar} H, 1 \mathrm{H}\right), 6.39$ (d, $J_{\mathrm{H}-\mathrm{H}}=8.0 \mathrm{~Hz}, \operatorname{Ar} H$, 2H), 2.35-2.41 (m, $\left.\mathrm{CH}\left(\mathrm{CH}_{3}\right)_{2}, 4 \mathrm{H}\right), 1.28-1.42\left(\mathrm{~m}, \mathrm{CH}\left(\mathrm{CH}_{3}\right)_{2}, 24 \mathrm{H}\right) .{ }^{13} \mathrm{C}\left\{{ }^{1} \mathrm{H}\right\}$ NMR $\left(101 \mathrm{MHz}, \mathrm{CDCl}_{3}, \delta\right): 169.06\left(\mathrm{t}, J_{\mathrm{P}-\mathrm{C}}=9.8 \mathrm{~Hz}, \mathrm{ArC}\right), 146.27(\mathrm{~s}, \mathrm{NCS}), 129.74(\mathrm{~s}$, $\operatorname{ArC}), 124.22\left(\mathrm{t}, J_{\mathrm{P}-\mathrm{C}}=21.3 \mathrm{~Hz}, \operatorname{ArC}\right), 105.57\left(\mathrm{t}, J_{\mathrm{P}-\mathrm{C}}=6.0 \mathrm{~Hz}, \operatorname{Ar} C\right), 28.17\left(\mathrm{t}, J_{\mathrm{C}-\mathrm{P}}=\right.$ $\left.11.3 \mathrm{~Hz}, \quad \mathrm{CH}\left(\mathrm{CH}_{3}\right)_{2}\right), \quad 17.45$ (t, $\left.J_{\mathrm{C}-\mathrm{P}}=3.0 \mathrm{~Hz}, \quad \mathrm{CH}\left(\mathrm{CH}_{3}\right)_{2}\right), 16.82 \quad(\mathrm{~s}$, $\left.\mathrm{CH}\left(\mathrm{CH}_{3}\right)_{2}\right) .{ }^{31} \mathrm{P}\left\{{ }^{1} \mathrm{H}\right\}$ NMR $\left(162 \mathrm{MHz}, \mathrm{CDCl}_{3}, \delta\right): 188.57$ (s). FTIR (KBr): $v_{\mathrm{CN}}=$ $2091 \mathrm{~cm}^{-1}$. Anal. Calcd for $\mathrm{C}_{19} \mathrm{H}_{31} \mathrm{NO}_{2} \mathrm{P}_{2} \mathrm{SNi}$ C, 49.81; H, 6.82; N, 3.06. Found: $\mathrm{C}$, $49.85 ; \mathrm{H}, 6.68, \mathrm{~N}, 3.06$. 
Synthesis of $\left[2,6-\left(\mathrm{Ph}_{2} \mathrm{PO}\right)_{2} \mathrm{C}_{6} \mathrm{H}_{3}\right] \mathrm{Ni}(\underline{\mathrm{NCS}})(\mathbf{2 a c})$

Complex 2ac was prepared from 1ac and $\mathrm{KSCN}$ in $91 \%$ (room temperature) or $75 \%$ (under refluxing) yield by procedures similar to those used for $2 \mathbf{a a} .{ }^{1} \mathrm{H}$ NMR (400 MHz, $\left.\mathrm{CDCl}_{3}, \delta\right): 7.86-7.89$ (m, $\left.\mathrm{ArH}, 8 \mathrm{H}\right), 7.51-7.55$ (m, ArH, 12H), $7.11\left(\mathrm{t}, J_{\mathrm{H}-\mathrm{H}}\right.$ $=8.0 \mathrm{~Hz}, \operatorname{Ar} H, 1 \mathrm{H}), 6.65\left(\mathrm{~d}, J_{\mathrm{H}-\mathrm{H}}=8.0 \mathrm{~Hz}, \operatorname{Ar} H, 2 \mathrm{H}\right) .{ }^{13} \mathrm{C}\left\{{ }^{1} \mathrm{H}\right\} \mathrm{NMR}(101 \mathrm{MHz}$, $\left.\mathrm{CDCl}_{3}, \delta\right): 167.51\left(\mathrm{t}, J_{\mathrm{P}-\mathrm{C}}=11.3 \mathrm{~Hz}, \mathrm{ArC}\right), 145.69$ (s, NCS), 132.37 (s, ArC), 131.81 $\left(\mathrm{t}, J_{\mathrm{P}-\mathrm{C}}=24.8 \mathrm{~Hz}, \operatorname{ArC}\right), 131.55\left(\mathrm{t}, J_{\mathrm{P}-\mathrm{C}}=7.5 \mathrm{~Hz}, \operatorname{Ar} C\right), 130.65(\mathrm{~s}, \operatorname{ArC}), 129.29$ (t, $J_{\mathrm{P}-\mathrm{C}}$ $=5.2 \mathrm{~Hz}, \operatorname{ArC}), 125.13\left(\mathrm{t}, J_{\mathrm{P}-\mathrm{C}}=23.9 \mathrm{~Hz}, \operatorname{ArC}\right), 107.01\left(\mathrm{t}, J_{\mathrm{P}-\mathrm{C}}=7.0 \mathrm{~Hz}, \operatorname{ArC}\right) .{ }^{31} \mathrm{P}\left\{{ }^{1} \mathrm{H}\right\}$ NMR (162 MHz, $\left.\mathrm{CDCl}_{3}, \delta\right): 144.59$ (s). FTIR (KBr): $v_{\mathrm{CN}}=2072 \mathrm{~cm}^{-1}$. Anal. Calcd for $\mathrm{C}_{31} \mathrm{H}_{23} \mathrm{NO}_{2} \mathrm{P}_{2} \mathrm{SNi}$ : C, 62.66; H, 3.90; N, 2.36. Found: C, 62.38; H, 4.12; N, 2.40.

Synthesis of $\left[4-\mathrm{CO}_{2} \mathrm{Me}-2,6-\left({ }^{t} \mathrm{Bu}{ }_{2} \mathrm{PO}\right){ }_{2} \mathrm{C}_{6} \mathrm{H}_{2}\right] \mathrm{Ni}(\underline{\mathrm{NCS}})(\mathbf{2 b a})$

Complex 2 ba was prepared from $\mathbf{1 b a}$ and $\mathrm{KSCN}$ in $86 \%$ (room temperature) or $65 \%$ (under refluxing) yield by procedures similar to those used for $2 \mathbf{a a} .{ }^{1} \mathrm{H}$ NMR $\left(400 \mathrm{MHz}, \mathrm{CDCl}_{3}, \delta\right): 7.07(\mathrm{~s}, \mathrm{ArH}, 2 \mathrm{H}), 3.85\left(\mathrm{~s}, \mathrm{OCH}_{3}, 3 \mathrm{H}\right), 1.45\left(\mathrm{t}, J_{\mathrm{P}-\mathrm{H}}=7.2 \mathrm{~Hz}\right.$, $\left.\mathrm{C}\left(\mathrm{CH}_{3}\right)_{3}, 36 \mathrm{H}\right) .{ }^{13} \mathrm{C}\left\{{ }^{1} \mathrm{H}\right\} \mathrm{NMR}\left(101 \mathrm{MHz}, \mathrm{CDCl}_{3}, \delta\right): 169.53\left(\mathrm{t}, J_{\mathrm{P}-\mathrm{C}}=9.1 \mathrm{~Hz}, \operatorname{ArC}\right)$, $166.78\left(\mathrm{~s}, \mathrm{CO}_{2} \mathrm{CH}_{3}\right), 147.65(\mathrm{~s}, \mathrm{NCS}), 133.16\left(\mathrm{t}, J_{\mathrm{P}-\mathrm{C}}=20.2 \mathrm{~Hz}, \mathrm{ArC}\right), 131.52(\mathrm{~s}$, $\mathrm{ArC}), 106.39\left(\mathrm{t}, J_{\mathrm{P}-\mathrm{C}}=6.1 \mathrm{~Hz}, \operatorname{ArC}\right), 52.22\left(\mathrm{~s}, \mathrm{CO}_{2} C_{3}\right), 39.42\left(\mathrm{t}, J_{\mathrm{P}-\mathrm{C}}=7.1 \mathrm{~Hz}\right.$, $\left.C\left(\mathrm{CH}_{3}\right)_{3}\right), 27.79\left(\mathrm{t}, J_{\mathrm{P}-\mathrm{C}}=3.0 \mathrm{~Hz}, \mathrm{C}\left(\mathrm{CH}_{3}\right)_{3}\right) .{ }^{31} \mathrm{P}\left\{{ }^{1} \mathrm{H}\right\} \mathrm{NMR}\left(162 \mathrm{MHz}, \mathrm{CDCl}_{3}, \delta\right)$ : 195.18 (s). FTIR (KBr): $v_{\mathrm{CN}}=2098 \mathrm{~cm}^{-1}$. Anal. Calcd for $\mathrm{C}_{25} \mathrm{H}_{41} \mathrm{NO}_{4} \mathrm{P}_{2} \mathrm{SNi}: \mathrm{C}, 52.47$; H, 7.22; N, 2.45. Found: C, 52.37; H, 7.23; N, 2.45 .

Synthesis of $\left[4-\mathrm{CO}_{2} \mathrm{Me}-2,6-\left(\mathrm{Pr}_{2} \mathrm{PO}\right)_{2} \mathrm{C}_{6} \mathrm{H}_{2}\right] \mathrm{Ni}(\mathrm{NCS})(\mathbf{2 b \boldsymbol { b }})$

Complex $\mathbf{2 b b}$ was prepared from $\mathbf{1 b b}$ and $\mathrm{KSCN}$ in $93 \%$ (room temperature) or $78 \%$ (under refluxing) yield by procedures similar to those used for $\mathbf{2 a a} .{ }^{1} \mathrm{H}$ NMR (400 MHz, $\left.\mathrm{CDCl}_{3}, \delta\right): 7.08(\mathrm{~s}, \mathrm{ArH}, 2 \mathrm{H}), 3.85\left(\mathrm{~s}, \mathrm{OCH}_{3}, 3 \mathrm{H}\right), 2.39-2.47$ (m, $\left.\mathrm{C} H\left(\mathrm{CH}_{3}\right)_{2}, 4 \mathrm{H}\right), 1.30-1.44\left(\mathrm{~m}, \mathrm{CH}\left(\mathrm{CH}_{3}\right)_{2}, 24 \mathrm{H}\right) .{ }^{13} \mathrm{C}\left\{{ }^{1} \mathrm{H}\right\}$ NMR $\left(101 \mathrm{MHz}, \mathrm{CDCl}_{3}, \delta\right)$ : $168.80\left(\mathrm{t}, J_{\mathrm{P}-\mathrm{C}}=10.1 \mathrm{~Hz}, \mathrm{ArC}\right), 166.62\left(\mathrm{~s}, \mathrm{CO}_{2} \mathrm{CH}_{3}\right), 147.11(\mathrm{~s}, \mathrm{NCS}), 132.58\left(\mathrm{t}, J_{\mathrm{P}-\mathrm{C}}\right.$ $=20.2 \mathrm{~Hz}, \operatorname{ArC}), 131.93(\mathrm{~s}, \mathrm{ArC}), 106.58\left(\mathrm{t}, J_{\mathrm{P}-\mathrm{C}}=7.1 \mathrm{~Hz}, \mathrm{ArC}\right), 52.23\left(\mathrm{~s}, \mathrm{CO}_{2} \mathrm{CH}_{3}\right)$, 
$28.31\left(\mathrm{t}, J_{\mathrm{P}-\mathrm{C}}=12.1 \mathrm{~Hz}, \mathrm{CH}\left(\mathrm{CH}_{3}\right)_{2}\right), 17.41\left(\mathrm{t}, J_{\mathrm{C}-\mathrm{P}}=3.0 \mathrm{~Hz}, \mathrm{CH}\left(\mathrm{CH}_{3}\right)_{2}\right), 16.80(\mathrm{~s}$, $\left.\mathrm{CH}\left(\mathrm{CH}_{3}\right)_{2}\right) .{ }^{31} \mathrm{P}\left\{{ }^{1} \mathrm{H}\right\} \operatorname{NMR}\left(162 \mathrm{MHz}, \mathrm{CDCl}_{3}, \delta\right): 189.85$ (s). FTIR $(\mathrm{KBr}): v_{\mathrm{CN}}=$ $2082 \mathrm{~cm}^{-1}, v_{\mathrm{CO}}=1721 \mathrm{~cm}^{-1}$. Anal. Calcd for $\mathrm{C}_{21} \mathrm{H}_{33} \mathrm{NO}_{4} \mathrm{P}_{2} \mathrm{SNi}$ C, 48.86; H, 6.44; N, 2.71. Found: C, 48.88; H, 6.44; N, 2.72 .

\section{Synthesis of $\left[4-\mathrm{CO}_{2} \mathrm{Me}-2,6-\left(\mathrm{Ph}_{2} \mathrm{PO}\right)_{2} \mathrm{C}_{6} \mathrm{H}_{2}\right] \mathrm{Ni}(\underline{\mathrm{NCS}})(\mathbf{2 b c})$}

Complex 2 bc was prepared from 1 bc and $\mathrm{KSCN}$ in 90\% (room temperature) or $65 \%$ (under refluxing) yield by procedures similar to those used for 2 aa. ${ }^{1} \mathrm{H}$ NMR $\left(400 \mathrm{MHz}, \mathrm{CDCl}_{3}, \delta\right): 7.83-7.88(\mathrm{~m}, \mathrm{ArH}, 8 \mathrm{H}), 7.51-7.60(\mathrm{~m}, \mathrm{Ar} H, 12 \mathrm{H}), 7.28(\mathrm{~s}$, $\mathrm{ArH}, 2 \mathrm{H}), 3.87\left(\mathrm{~s}, \mathrm{OCH}_{3}, 3 \mathrm{H}\right) .{ }^{13} \mathrm{C}\left\{{ }^{1} \mathrm{H}\right\} \mathrm{NMR}\left(101 \mathrm{MHz}, \mathrm{CDCl}_{3}, \delta\right): 167.17\left(\mathrm{t}, J_{\mathrm{P}-\mathrm{C}}=\right.$ $11.1 \mathrm{~Hz}, \mathrm{ArC}$ ), 166.34 (s, $\mathrm{CO}_{2} \mathrm{CH}_{3}$ ), 146.33 (s, NCS), 133.27 (t, $J_{\mathrm{P}-\mathrm{C}}=23.2 \mathrm{~Hz}, \mathrm{ArC}$ ), $132.69(\mathrm{~s}, \operatorname{Ar} C), 132.58(\mathrm{~s}, \operatorname{ArC}), 131.51\left(\mathrm{t}, J_{\mathrm{P}-\mathrm{C}}=7.1 \mathrm{~Hz}, \operatorname{ArC}\right), 131.35\left(\mathrm{t}, J_{\mathrm{P}-\mathrm{C}}=25.3\right.$ $\mathrm{Hz}, \operatorname{ArC}), 129.38\left(\mathrm{t}, J_{\mathrm{P}-\mathrm{C}}=5.1 \mathrm{~Hz}, \operatorname{ArC}\right), 107.89\left(\mathrm{t}, J_{\mathrm{P}-\mathrm{C}}=8.1 \mathrm{~Hz}, \operatorname{ArC}\right), 52.37(\mathrm{~s}$, $\left.\mathrm{CO}_{2} \mathrm{CH}_{3}\right) .{ }^{31} \mathrm{P}\left\{{ }^{1} \mathrm{H}\right\}$ NMR $\left(162 \mathrm{MHz}, \mathrm{CDCl}_{3}, \delta\right): 145.02$ (s). FTIR $(\mathrm{KBr}): v_{\mathrm{CN}}=2071$ $\mathrm{cm}^{-1}, v_{\mathrm{CO}}=1715 \mathrm{~cm}^{-1}$. Anal. Calcd for $\mathrm{C}_{33} \mathrm{H}_{25} \mathrm{NO}_{4} \mathrm{P}_{2} \mathrm{SNi}$ : C, 60.77; H, 3.86; N, 2.15 . Found: C, 60.43; H, 3.94; N, 2.12 .

Synthesis of $\left[2,6-\left({ }^{t} \mathrm{Bu}_{2} \mathrm{PO}\right){ }_{2} \mathrm{C}_{6} \mathrm{H}_{3}\right] \mathrm{NiN}_{3}(\mathbf{3 a a})$

A mixture of $\quad\left[2,6-\left({ }^{\mathrm{t}} \mathrm{Bu}_{2} \mathrm{PO}\right)_{2} \mathrm{C}_{6} \mathrm{H}_{3}\right] \mathrm{NiCl}$ (1aa) (492 mg, 1 mmol), $\mathrm{NaN}_{3}(325 \mathrm{mg}$, $5 \mathrm{mmol})$, THF $(10 \mathrm{~mL})$ and $\mathrm{MeOH}(10 \mathrm{~mL})$ was stirred in a sealed flask at room temperature for $5 \mathrm{~d}$. The volatiles were removed under vacuum and the residue was extracted with toluene and then filtered through a pad of Celite. Removal of toluene under vacuum produced 3 aa as an orange solid (451 mg, 91\% yield). ${ }^{1} \mathrm{H}$ NMR (400 $\left.\mathrm{MHz}, \mathrm{CDCl}_{3}, \delta\right): 6.92\left(\mathrm{t}, J_{\mathrm{H}-\mathrm{H}}=8.0 \mathrm{~Hz}, \mathrm{ArH}, 1 \mathrm{H}\right), 6.38\left(\mathrm{~d}, J_{\mathrm{H}-\mathrm{H}}=8.0 \mathrm{~Hz}, \operatorname{Ar} H, 2 \mathrm{H}\right)$, $1.46\left(\mathrm{t}, J_{\mathrm{P}-\mathrm{H}}=8.0 \mathrm{~Hz}, \mathrm{CH}_{3}, 36 \mathrm{H}\right) .{ }^{13} \mathrm{C}\left\{{ }^{1} \mathrm{H}\right\} \mathrm{NMR}\left(101 \mathrm{MHz}, \mathrm{CDCl}_{3}, \delta\right): 169.79\left(\mathrm{t}, J_{\mathrm{P}-\mathrm{C}}\right.$ $=9.6 \mathrm{~Hz}, \operatorname{ArC}), 128.77(\mathrm{~s}, \operatorname{ArC}), 123.86\left(\mathrm{t}, J_{\mathrm{P}-\mathrm{C}}=20.2 \mathrm{~Hz}, \operatorname{ArC}\right), 105.24\left(\mathrm{t}, J_{\mathrm{P}-\mathrm{C}}=5.9\right.$ $\mathrm{Hz}, \mathrm{ArC}), 38.94\left(\mathrm{t}, J_{\mathrm{P}-\mathrm{C}}=7.2 \mathrm{~Hz}, C\left(\mathrm{CH}_{3}\right)_{3}\right), 27.83\left(\mathrm{t}, J_{\mathrm{P}-\mathrm{C}}=3.0 \mathrm{~Hz}, C \mathrm{H}_{3}\right) .{ }^{31} \mathrm{P}\left\{{ }^{1} \mathrm{H}\right\}$ NMR (162 MHz, $\left.\mathrm{CDCl}_{3}, \delta\right): 189.85$. FTIR (KBr): $v_{\mathrm{N} 3}=2072 \mathrm{~cm}^{-1}$. Anal. Calcd for $\mathrm{C}_{22} \mathrm{H}_{39} \mathrm{~N}_{3} \mathrm{O}_{2} \mathrm{P}_{2} \mathrm{Ni}$ : C, 53.04; H, 7.89; N, 8.43. Found: C, 53.17; H, 7.93. N, 8.39.

Alternatively, a mixture of $\left[2,6-\left({ }^{\mathrm{t}} \mathrm{Bu}{ }_{2} \mathrm{PO}\right)_{2} \mathrm{C}_{6} \mathrm{H}_{3}\right] \mathrm{NiCl}$ (1aa) $(492 \mathrm{mg}, 1 \mathrm{mmol})$, 
$\mathrm{NaN}_{3}(325 \mathrm{mg}, 5 \mathrm{mmol})$, THF $(10 \mathrm{~mL})$ and methanol $(10 \mathrm{~mL})$ was refluxed under a nitrogen atmosphere for $24 \mathrm{~h}$. After cooling to room temperature, the volatiles were removed under vacuum and the residue was extracted with toluene and then filtered through a pad of Celite. Removal of toluene under vacuum followed by recrystallization in $\mathrm{CH}_{2} \mathrm{Cl}_{2} / n$-hexane produced 3aa as orange crystals (348 mg, 70\% yield).

\section{Synthesis of $\left[2,6-\left(\mathrm{Pr}_{2} \mathrm{PO}\right)_{2} \mathrm{C}_{6} \mathrm{H}_{3}\right] \mathrm{NiN}_{3}(3 \boldsymbol{a b})$}

Complex 3ab was prepared from $\mathbf{1 a b}$ and $\mathrm{NaN}_{3}$ in $89 \%$ (room temperature) or $78 \%$ (under refluxing) yield by procedures similar to those used for 3aa. ${ }^{1} \mathrm{H}$ NMR $\left(400 \mathrm{MHz}, \mathrm{CDCl}_{3}, \delta\right): 6.94\left(\mathrm{t}, J_{\mathrm{H}-\mathrm{H}}=8.0 \mathrm{~Hz}, \mathrm{ArH}, 1 \mathrm{H}\right), 6.39\left(\mathrm{~d}, J_{\mathrm{H}-\mathrm{H}}=8.0 \mathrm{~Hz}, \mathrm{ArH}\right.$, 2H), 2.36-2.43 (m, $\left.\mathrm{CH}\left(\mathrm{CH}_{3}\right)_{2}, 4 \mathrm{H}\right), 1.31-1.45\left(\mathrm{~m}, \mathrm{CH}\left(\mathrm{CH}_{3}\right)_{2}, 24 \mathrm{H}\right) .{ }^{13} \mathrm{C}\left\{{ }^{1} \mathrm{H}\right\} \mathrm{NMR}$ $\left(101 \mathrm{MHz}, \mathrm{CDCl}_{3}, \delta\right): 168.85\left(\mathrm{t}, J_{\mathrm{P}-\mathrm{C}}=10.1 \mathrm{~Hz}, \mathrm{ArC}\right), 129.11(\mathrm{~s}, \mathrm{ArC}), 124.44\left(\mathrm{t}, J_{\mathrm{P}-\mathrm{C}}\right.$ $=20.2 \mathrm{~Hz}, \mathrm{ArC}), 105.42\left(\mathrm{t}, J_{\mathrm{P}-\mathrm{C}}=6.1 \mathrm{~Hz}, \mathrm{ArC}\right), 27.96\left(\mathrm{t}, J_{\mathrm{C}-\mathrm{P}}=10.1 \mathrm{~Hz}, \mathrm{CH}\left(\mathrm{CH}_{3}\right)_{2}\right)$, $17.33\left(\mathrm{t}, J_{\mathrm{C}-\mathrm{P}}=4.0 \mathrm{~Hz}, \mathrm{CH}\left(\mathrm{CH}_{3}\right)_{2}\right), 16.82\left(\mathrm{~s}, \mathrm{CH}\left(\mathrm{CH}_{3}\right)_{2}\right) .{ }^{31} \mathrm{P}\left\{{ }^{1} \mathrm{H}\right\} \mathrm{NMR}(162 \mathrm{MHz}$, $\mathrm{CDCl}_{3}, \delta$ ): 185.17 (s). FTIR (KBr): $v_{\mathrm{N} 3}=2053 \mathrm{~cm}^{-1}$. Anal. Calcd for $\mathrm{C}_{18} \mathrm{H}_{31} \mathrm{~N}_{3} \mathrm{O}_{2} \mathrm{P}_{2} \mathrm{Ni}$ : C, 48.90; H, 7.07; N, 9.50. Found: C, 48.73; H, 7.05; N, 9.40.

\section{Synthesis of $\left[2,6-\left(\mathrm{Ph}_{2} \mathrm{PO}\right)_{2} \mathrm{C}_{6} \mathrm{H}_{3}\right] \mathrm{NiN}_{3}(\mathbf{3 a c})$}

Complex 3ac was prepared from 1 ac and $\mathrm{NaN}_{3}$ in $88 \%$ (room temperature) or $60 \%$ (under refluxing) yield by procedures similar to those used for 3aa. ${ }^{1} \mathrm{H}$ NMR (400 MHz, $\left.\mathrm{CDCl}_{3}, \delta\right): 7.88-7.92$ (m, $\left.\mathrm{ArH}, 8 \mathrm{H}\right), 7.49-7.57$ (m, $\left.\mathrm{ArH}, 12 \mathrm{H}\right), 7.07$ (t, $J_{\mathrm{H}-\mathrm{H}}$ $=8.0 \mathrm{~Hz}, \operatorname{Ar} H, 1 \mathrm{H}), 6.60\left(\mathrm{~d}, J_{\mathrm{H}-\mathrm{H}}=8.0 \mathrm{~Hz}, \operatorname{Ar} H, 2 \mathrm{H}\right) .{ }^{13} \mathrm{C}\left\{{ }^{1} \mathrm{H}\right\} \mathrm{NMR}(101 \mathrm{MHz}$, $\left.\mathrm{CDCl}_{3}, \delta\right): 167.26\left(\mathrm{t}, J_{\mathrm{P}-\mathrm{C}}=11.4 \mathrm{~Hz}, \operatorname{ArC}\right), 132.23(\mathrm{~s}, \operatorname{ArC}), 132.13\left(\mathrm{t}, J_{\mathrm{P}-\mathrm{C}}=23.8 \mathrm{~Hz}\right.$, $\operatorname{ArC}), 131.76\left(\mathrm{t}, J_{\mathrm{P}-\mathrm{C}}=8.0 \mathrm{~Hz}, \operatorname{ArC}\right), 130.00(\mathrm{~s}, \operatorname{ArC}), 129.16\left(\mathrm{t}, J_{\mathrm{P}-\mathrm{C}}=5.6 \mathrm{~Hz}, \operatorname{ArC}\right)$, $125.37\left(\mathrm{t}, J_{\mathrm{P}-\mathrm{C}}=24.4 \mathrm{~Hz}, \operatorname{ArC}\right), 106.81\left(\mathrm{t}, J_{\mathrm{P}-\mathrm{C}}=7.2 \mathrm{~Hz}, \operatorname{ArC}\right) .{ }^{31} \mathrm{P}\left\{{ }^{1} \mathrm{H}\right\} \operatorname{NMR}(162$ $\left.\mathrm{MHz}, \mathrm{CDCl}_{3}, \delta\right): 142.47$ (s). FTIR $(\mathrm{KBr}): v_{\mathrm{N} 3}=2048 \mathrm{~cm}^{-1}$. Anal. Calcd for $\mathrm{C}_{30} \mathrm{H}_{23} \mathrm{~N}_{3} \mathrm{O}_{2} \mathrm{P}_{2} \mathrm{Ni}$ : C, 62.32; H, 4.01; N, 7.27. Found: C, 62.56; H, 3.98; N, 7.46. 
Synthesis of $\left[4-\mathrm{CO}_{2} \mathrm{Me}-2,6-\left({ }^{\mathrm{B}} \mathrm{Bu}{ }_{2} \mathrm{PO}\right)_{2} \mathrm{C}_{6} \mathrm{H}_{2}\right] \mathrm{NiN}_{3}(\mathbf{3 b a})$

Complex 3 ba was prepared from $\mathbf{1 b a}$ and $\mathrm{NaN}_{3}$ in $90 \%$ (room temperature) or $60 \%$ (under refluxing) yield by procedures similar to those used for 3aa. ${ }^{1} \mathrm{H}$ NMR (400 MHz, $\left.\mathrm{CDCl}_{3}, \delta\right): 7.05(\mathrm{~s}, \mathrm{ArH}, 2 \mathrm{H}), 3.85\left(\mathrm{~s}, \mathrm{OCH}_{3}, 3 \mathrm{H}\right), 1.46\left(\mathrm{t}, J_{\mathrm{P}-\mathrm{H}}=7.2 \mathrm{~Hz}\right.$, $\left.\mathrm{C}\left(\mathrm{CH}_{3}\right)_{3}, 36 \mathrm{H}\right) .{ }^{13} \mathrm{C}\left\{{ }^{1} \mathrm{H}\right\} \mathrm{NMR}\left(101 \mathrm{MHz}, \mathrm{CDCl}_{3}, \delta\right): 169.46\left(\mathrm{t}, J_{\mathrm{P}-\mathrm{C}}=10.1 \mathrm{~Hz}, \mathrm{ArC}\right)$, $166.97\left(\mathrm{~s}, \mathrm{CO}_{2} \mathrm{CH}_{3}\right), 132.85\left(\mathrm{t}, J_{\mathrm{P}-\mathrm{C}}=20.2 \mathrm{~Hz}, \mathrm{ArC}\right), 131.03(\mathrm{~s}, \mathrm{ArC}), 106.23\left(\mathrm{t}, J_{\mathrm{P}-\mathrm{C}}=\right.$ $5.9 \mathrm{~Hz}, \mathrm{ArC}), 52.18\left(\mathrm{~s}, \mathrm{CO}_{2} \mathrm{CH}_{3}\right), 39.20\left(\mathrm{t}, J_{\mathrm{P}-\mathrm{C}}=7.1 \mathrm{~Hz}, C\left(\mathrm{CH}_{3}\right)_{3}\right), 27.76\left(\mathrm{t}, J_{\mathrm{P}-\mathrm{C}}=\right.$ $\left.3.0 \mathrm{~Hz}, \mathrm{C}\left(\mathrm{CH}_{3}\right)_{3}\right) \cdot{ }^{31} \mathrm{P}\left\{{ }^{1} \mathrm{H}\right\} \mathrm{NMR}\left(162 \mathrm{MHz}, \mathrm{CDCl}_{3}, \delta\right): 191.13(\mathrm{~s})$. FTIR $(\mathrm{KBr}): v_{\mathrm{N} 3}=$ $2073 \mathrm{~cm}^{-1}, v_{\mathrm{CO}}=1719 \mathrm{~cm}^{-1}$. Anal. Calcd for $\mathrm{C}_{24} \mathrm{H}_{41} \mathrm{~N}_{3} \mathrm{O}_{4} \mathrm{P}_{2} \mathrm{Ni}: \mathrm{C}, 51.82 ; \mathrm{H}, 7.43 ; \mathrm{N}$, 7.55. Found: C, 51.98; H, 7.53; N, 7.46.

Synthesis of $\left[4-\mathrm{CO}_{2} \mathrm{Me}-2,6-\left({ }^{i} \mathrm{Pr}_{2} \mathrm{PO}\right)_{2} \mathrm{C}_{6} \mathrm{H}_{2}\right] \mathrm{NiN}_{3}(\mathbf{3} \boldsymbol{b} \boldsymbol{b})$

Complex $\mathbf{3 b b}$ was prepared from $\mathbf{1 b b}$ and $\mathrm{NaN}_{3}$ in $92 \%$ (room temperature) or $60 \%$ (under refluxing) yield by procedures similar to those used for 3aa. ${ }^{1} \mathrm{H}$ NMR (400 MHz, $\left.\mathrm{CDCl}_{3}, \delta\right): 7.06(\mathrm{~s}, \mathrm{ArH}, 2 \mathrm{H}), 3.85$ (s, $\left.\mathrm{OCH}_{3}, 3 \mathrm{H}\right), 2.38-2.45$ (m, $\left.\mathrm{CH}\left(\mathrm{CH}_{3}\right)_{2}, 4 \mathrm{H}\right), 1.30-1.45\left(\mathrm{~m}, \mathrm{CH}\left(\mathrm{CH}_{3}\right)_{2}, 24 \mathrm{H}\right) .{ }^{13} \mathrm{C}\left\{{ }^{1} \mathrm{H}\right\}$ NMR $\left(101 \mathrm{MHz}, \mathrm{CDCl}_{3}, \delta\right)$ : $168.52\left(\mathrm{t}, J_{\mathrm{P}-\mathrm{C}}=10.1 \mathrm{~Hz}, \mathrm{ArC}\right), 166.84\left(\mathrm{~s}, \mathrm{CO}_{2} \mathrm{CH}_{3}\right), 133.25\left(\mathrm{t}, J_{\mathrm{P}-\mathrm{C}}=21.2 \mathrm{~Hz}, \mathrm{ArC}\right)$, $131.28(\mathrm{~s}, \mathrm{ArC}), 106.40\left(\mathrm{t}, J_{\mathrm{P}-\mathrm{C}}=6.1 \mathrm{~Hz}, \mathrm{ArC}\right), 52.18\left(\mathrm{~s}, \mathrm{CO}_{2} \mathrm{CH}_{3}\right), 28.04\left(\mathrm{t}, J_{\mathrm{P}-\mathrm{C}}=\right.$ $\left.11.1 \mathrm{~Hz}, \mathrm{CH}\left(\mathrm{CH}_{3}\right)_{2}\right), 17.25\left(\mathrm{t}, J_{\mathrm{C}-\mathrm{P}}=3.0 \mathrm{~Hz}, \mathrm{CH}\left(\mathrm{CH}_{3}\right)_{2}\right), 16.75\left(\mathrm{~s}, \mathrm{CH}\left(\mathrm{CH}_{3}\right)_{2}\right) .{ }^{31} \mathrm{P}\left\{{ }^{1} \mathrm{H}\right\}$ NMR (162 MHz, $\left.\mathrm{CDCl}_{3}, \delta\right): 186.56(\mathrm{~s})$. FTIR (KBr): $v_{\mathrm{N} 3}=2047 \mathrm{~cm}^{-1}, v_{\mathrm{CO}}=1715$ $\mathrm{cm}^{-1}$. Anal. Calcd for $\mathrm{C}_{20} \mathrm{H}_{33} \mathrm{~N}_{3} \mathrm{O}_{4} \mathrm{P}_{2} \mathrm{Ni}$ : C, 48.03; H, 6.65; N, 8.40. Found: C, 48.04; H, 6.67; N, 8.35.

\section{Synthesis of $\left[4-\mathrm{CO}_{2} \mathrm{Me}-2,6-\left(\mathrm{Ph}_{2} \mathrm{PO}\right)_{2} \mathrm{C}_{6} \mathrm{H}_{2}\right] \mathrm{NiN}_{3}(3 \mathbf{b c})$}

Complex 3bc was prepared from $\mathbf{1 b c}$ and $\mathrm{NaN}_{3}$ in $91 \%$ (room temperature) or $60 \%$ (under refluxing) yield by procedures similar to those used for 3aa. ${ }^{1} \mathrm{H}$ NMR (400 MHz, $\left.\mathrm{CDCl}_{3}, \delta\right): 7.96-8.01$ (m, $\left.\mathrm{ArH}, 8 \mathrm{H}\right), 7.46-7.55$ (m, $\left.\mathrm{ArH}, 12 \mathrm{H}\right), 7.28$ (s, $\mathrm{Ar} H, 2 \mathrm{H}), 3.87\left(\mathrm{~s}, \mathrm{OCH}_{3}, 3 \mathrm{H}\right) .{ }^{13} \mathrm{C}\left\{{ }^{1} \mathrm{H}\right\} \mathrm{NMR}\left(101 \mathrm{MHz}, \mathrm{CDCl}_{3}, \delta\right): 166.93\left(\mathrm{t}, J_{\mathrm{P}-\mathrm{C}}=\right.$ 11.1 Hz, $\mathrm{ArC}$ ), $166.57\left(\mathrm{~s}, \mathrm{CO}_{2} \mathrm{CH}_{3}\right), 133.96$ (t, $\left.J_{\mathrm{P}-\mathrm{C}}=22.2 \mathrm{~Hz}, \mathrm{ArC}\right), 132.42(\mathrm{~s}, \mathrm{ArC})$, $131.92(\mathrm{~s}, \operatorname{ArC}), 131.73\left(\mathrm{t}, J_{\mathrm{P}-\mathrm{C}}=8.1 \mathrm{~Hz}, \operatorname{ArC}\right), 131.73\left(\mathrm{t}, J_{\mathrm{P}-\mathrm{C}}=24.2 \mathrm{~Hz}, \operatorname{Ar} C\right)$, 
$129.24\left(\mathrm{t}, J_{\mathrm{P}-\mathrm{C}}=5.1 \mathrm{~Hz}, \operatorname{ArC}\right), 107.71\left(\mathrm{t}, J_{\mathrm{P}-\mathrm{C}}=7.1 \mathrm{~Hz}, \operatorname{ArC}\right), 52.31(\mathrm{~s}$, $\left.\mathrm{CO}_{2} \mathrm{CH}_{3}\right) .{ }^{31} \mathrm{P}\left\{{ }^{1} \mathrm{H}\right\}$ NMR $\left(162 \mathrm{MHz}, \mathrm{CDCl}_{3}, \delta\right): 143.09$ (s). FTIR (KBr): $v_{\mathrm{N} 3}=2049$ $\mathrm{cm}^{-1}, v_{\mathrm{CO}}=1716 \mathrm{~cm}^{-1}$. Anal. Calcd for $\mathrm{C}_{32} \mathrm{H}_{25} \mathrm{~N}_{3} \mathrm{O}_{4} \mathrm{P}_{2} \mathrm{Ni}$ : C, 60.41; H, 3.96; N, 6.60. Found: C, 60.57; H, 3.93; N, 6.65 .

Comparative study of the reactions of $\left[4-\mathrm{Z}-2,6-\left(\mathrm{R}_{2} \mathrm{PO}\right)_{2} \mathrm{C}_{6} \mathrm{H}_{2}\right] \mathrm{NiCl}$ with $\mathrm{KSCN}$ or $\mathrm{NaN}_{3}$

In a $25 \mathrm{~mL}$ flask, $0.10 \mathrm{mmol}$ of potassium thiocyanate or sodium azide was mixed with $3 \mathrm{~mL}$ of THF. The mixture was stirred at $0^{\circ} \mathrm{C}$ for $10 \mathrm{~min}$, followed by the addition of a [4-Z-2,6-( $\left.\left.\mathrm{R}_{2} \mathrm{PO}\right)_{2} \mathrm{C}_{6} \mathrm{H}_{2}\right] \mathrm{NiCl}\left(\mathrm{R}={ }^{\mathrm{t}} \mathrm{Bu},{ }^{\mathrm{i}} \mathrm{Pr}, \mathrm{Ph} ; \mathrm{Z}=\mathrm{H}, \mathrm{CO}_{2} \mathrm{Me}\right)$ solution $(0.10 \mathrm{mmol})$ in $3 \mathrm{~mL}$ of THF. The resulting reaction mixture was further stirred at $0^{\circ} \mathrm{C}$ for $5 \mathrm{~min}$, after which $15 \mathrm{~mL}$ of water was quickly added with stirring. The precipitate was collected by filtration, dried and analyzed by ${ }^{31} \mathrm{P}\left\{{ }^{1} \mathrm{H}\right\}$ NMR. The ratio between [4-Z-2,6- $\left.\left(\mathrm{R}_{2} \mathrm{PO}\right)_{2} \mathrm{C}_{6} \mathrm{H}_{2}\right] \mathrm{NiCl}$ and $\quad\left[4-\mathrm{Z}-2,6-\left(\mathrm{R}_{2} \mathrm{PO}\right)_{2} \mathrm{C}_{6} \mathrm{H}_{2}\right] \mathrm{NiNCS}$ or [4-Z-2,6- $\left.\left(\mathrm{R}_{2} \mathrm{PO}\right)_{2} \mathrm{C}_{6} \mathrm{H}_{2}\right] \mathrm{NiN}_{3}$ was determined based on ${ }^{31} \mathrm{P}\left\{{ }^{1} \mathrm{H}\right\}$ NMR integrations, from which the conversion was calculated.

\section{Equilibrium constant measurement for the isothiocyanate/azide exchange reactions}

The exchange reactions were carried out at room temperature $(\mathrm{T}=298 \mathrm{~K})$ in sealed NMR tubes using $\mathrm{CDCl}_{3}$ as the solvent. The reactions were monitored by ${ }^{31} \mathrm{P}\left\{{ }^{1} \mathrm{H}\right\}$ NMR spectroscopy. Three individual experiments were carried out for any given exchange reaction. As a representative example, for the exchange reaction of $\mathbf{3 a a}+\mathbf{2} \mathbf{b a} \rightleftharpoons \mathbf{2 a a}+\mathbf{3 b a}$, the three experiments were: (1) $5 \mathrm{mg}$ of $\mathbf{3 a a}$ and $5 \mathrm{mg}$ of 2ba were mixed with $0.5 \mathrm{~mL}$ of $\mathrm{CDCl}_{3}$ in a NMR tube; (2) $5 \mathrm{mg}$ of $2 \mathbf{a a}$ and $5 \mathrm{mg}$ of 3ba were mixed with $0.5 \mathrm{~mL}$ of $\mathrm{CDCl}_{3}$ in a NMR tube; (3) 2-3 $\mathrm{mg}$ of 3aa, 2-3 $\mathrm{mg}$ of 2ba, 2-3 mg of 2aa and 2-3 $\mathrm{mg}$ of $\mathbf{3} \mathbf{b a}$ were mixed with $0.5 \mathrm{~mL}$ of $\mathrm{CDCl}_{3}$ in a $\mathrm{NMR}$ tube. The NMR tubes were then sealed and the ${ }^{31} \mathrm{P}\left\{{ }^{1} \mathrm{H}\right\}$ NMR spectra were recorded every $8 \mathrm{~h}$. The equilibrium was considered to be established when the ratios of the NMR integration values were unchanged. Each reported equilibrium constant was the average of the values from the three experiments. 


\section{Quantum chemical analysis}

A quantum chemical analysis for the coordinating nitrogen atoms of $\mathrm{SCN}^{-}$and $\mathrm{N}_{3}{ }^{-}$was performed. The ground-state geometries were optimized by the second-order Møller-Plesset perturbation (MP2) method using the 6-311++G (d, p) basis set. Condensed values of local reactivity descriptors, described by conceptual density functional theory (CDFT) [15] were calculated according to the literature procedure [16]. The charges were obtained from the NPA population analysis. All calculations were carried out using the Gaussian 09 software package [17].

\section{X-ray structure determinations}

Single crystals of the nickel isothiocyanate and azide complexes were obtained from recrystallization in $\mathrm{CH}_{2} \mathrm{Cl}_{2} / n$-hexane. Single crystals of $\mathbf{1 b a}$ were grown from $\mathrm{CH}_{2} \mathrm{Cl}_{2}$. Crystal data collection and refinement parameters of 2aa, 2bb, 3ac and $3 \mathbf{b a}$ are summarized in Table 8. The data for the remaining nickel complexes can be found in Supplementary data (Appendix B). Intensity data were collected at $103 \mathrm{~K}$ for $2 \mathbf{a a}$, 2ba, 2bb, 2bc, 3aa, 3ba, 3bb and 3bc, and $296 \mathrm{~K}$ for 2ab and 3ac on a Bruker SMART6000 CCD diffractometer using graphite-monochromated MoK $\alpha$ radiation, $\lambda$ $=0.71073 \AA$. Intensity data of $\mathbf{2 a c}$ were collected at $150 \mathrm{~K}$ for on a Bruker SMART6000 CCD diffractometer using graphite-monochromated $\mathrm{CuK} \alpha$ radiation, $\lambda$ $=1.54178 \AA$. Intensity data of $\mathbf{1 b a}$ were collected at $150 \mathrm{~K}$ on a Bruker PHOTO100 CMOS detector at Beamline 11.3.1 at the Advanced Light Source (Lawrence Berkeley National Laboratory) using synchrotron radiation tuned to $\lambda=0.7749 \AA$. The frames were integrated with the Bruker APEX2 software package using a narrow-frame algorithm. The data were corrected for decay, Lorentz, and polarization effects as well as absorption and beam corrections based on the multi-scan technique. The structures were solved by a combination of direct methods in SHELXTL and the difference Fourier technique and refined by full-matrix least-squares procedures. Nonhydrogen atoms were refined with anisotropic displacement parameters. The $\mathrm{H}$-atoms were either located or calculated and subsequently treated with a riding model. Two independent molecules of $\mathbf{1 b c}$ crystallize in the lattice. Disorder is 
observed for some of the carbon atoms of the ${ }^{t} \mathrm{Bu}$ groups of $\mathbf{1 b c}$ and the nitrogen atoms of the $\mathrm{N}_{3}$ group of $\mathbf{3 a a}$; for $\mathbf{1 b c}$ a two-component disorder models is presented for $\mathrm{C} 10 \mathrm{~B} / \mathrm{C}$ and $\mathrm{C} 14 \mathrm{~B} / \mathrm{C}$, and for 3aa a two-component model with 85:15 occupancy is given. No solvent of crystallization is present in the lattice for any of the structures.

\section{Table 8}

Summary of crystallographic data and structure refinement for representative nickel complexes

\begin{tabular}{|c|c|c|c|c|}
\hline & $2 \mathbf{a a}$ & $2 b b$ & $3 a c$ & $3 \mathbf{b a}$ \\
\hline Empirical formula & $\mathrm{C}_{23} \mathrm{H}_{39} \mathrm{NNiO}_{2} \mathrm{P}_{2} \mathrm{~S}$ & $\mathrm{C}_{21} \mathrm{H}_{33} \mathrm{NNiO}_{4} \mathrm{P}_{2} \mathrm{~S}$ & $\mathrm{C}_{30} \mathrm{H}_{23} \mathrm{~N}_{3} \mathrm{NiO}_{2} \mathrm{P}_{2}$ & $\mathrm{C}_{24} \mathrm{H}_{41} \mathrm{~N}_{3} \mathrm{NiO}_{4} \mathrm{P}_{2}$ \\
\hline Formula weight & 514.26 & 516.19 & 578.14 & 556.25 \\
\hline Temp, K & $103(2)$ & $103(2)$ & $296(2)$ & $103(2)$ \\
\hline Crystal system & Triclinic & Orthorhombic & Orthorhombic & Orthorhombic \\
\hline Space group & $\mathrm{P}-1$ & Pca $2_{1}$ & $\mathrm{P} 2{ }_{1} 2_{1} 2_{1}$ & Pca $2_{1}$ \\
\hline$a, \AA$ & $8.3477(10)$ & $22.3789(10)$ & $9.290(2)$ & $25.048(2)$ \\
\hline$b, \AA$ & $12.0771(14)$ & $7.9931(4)$ & $14.067(3)$ & $8.6616(8)$ \\
\hline$c, \AA$ & $13.5837(16)$ & $14.1551(6)$ & $19.763(4)$ & $12.8253(7)$ \\
\hline$\alpha\left(^{\circ}\right)$ & $102.639(2)$ & 90.00 & 90.00 & 90.00 \\
\hline$\beta\left(^{\circ}\right)$ & $93.182(3)$ & 90.00 & 90.00 & 90.00 \\
\hline$\gamma\left({ }^{\circ}\right)$ & $103.943(2)$ & 90.00 & 90.00 & 90.00 \\
\hline Volume, $\AA^{3}$ & $1288.4(3)$ & $2532.0(2)$ & $2582.8(10)$ & $2782.5(4)$ \\
\hline Z & 2 & 4 & 4 & 4 \\
\hline$d_{\text {calc }}, \mathrm{g} \mathrm{cm}^{-3}$ & 1.326 & 1.354 & 1.487 & 1.328 \\
\hline$\lambda, \AA$ & 0.71073 & 0.71073 & 0.71073 & 0.71073 \\
\hline$\mu, \mathrm{mm}^{-1}$ & 0.977 & 1.001 & 0.910 & 0.845 \\
\hline No. of data collected & 49168 & 23360 & 23478 & 23633 \\
\hline No. of unique data & 13206 & 7884 & 5960 & 7688 \\
\hline$R_{\text {int }}$ & 0.1101 & 0.0686 & 0.0489 & 0.1216 \\
\hline Goodness-of-fit on $F^{2}$ & 0.977 & 0.833 & 1.059 & 0.986 \\
\hline$R_{1}, \mathrm{w} R_{2}(I>2 \sigma(I))$ & $0.0597,0.1219$ & $0.0385,0.0616$ & $0.0390,0.0988$ & $0.0627,0.1100$ \\
\hline$R_{1}, \mathrm{w} R_{2}$ (all data) & $0.1208,0.1483$ & $0.0479,0.0643$ & $0.0432,0.1051$ & $0.1017,0.1270$ \\
\hline
\end{tabular}

\section{Acknowledgments}

This work was supported by the National Natural Science Foundation of China (Grant Nos. 21571052, to J.Z., 21371051, to X.C.), the Key Science and Technology Project of Henan Province (152102210085, to J.Z.), the Training Program of the National Natural Science Foundation of China from Henan Normal University (5101039279102, to J.Z.), the U.S. National Science Foundation (CHE-0952083 and 
CHE-1464734, to H.G.) and the Alfred P. Sloan Foundation (research fellowship to H.G.). Data for $\mathbf{1 b a}$ were collected through the SCrALS (Service Crystallography at Advanced Light Source) program at Beamline 11.3.1 at the Advanced Light Source (ALS), Lawrence Berkeley National Laboratory. The ALS is supported by the U.S. Department of Energy, Office of Energy Sciences Materials Sciences Division, under contract DE-AC02-05CH11231. Data for 2ac were collected at the University of Cincinnati on a Bruker SMART6000 diffractometer which was funded by an NSF-MRI grant (CHE-0215950).

\section{Appendix A. Supplementary material}

CCDC 1404255 (1ba), 1404256 (2ac), 1034585 (2ab), 1034586 (2bb), 1034587 (3ac), 1404901 (2ba), 1404902 (2bc), 1404903 (3aa), 1404904 (3ba), 1404905 (3bc), 1404906 (2aa) and 1404907 (3bb) contain the supplementary crystallographic data for this paper. These data can be obtained free of charge from The Cambridge Crystallographic Data Centre via www.ccdc.cam.ac.uk/data request/cif.

\section{Appendix B. Supplementary material}

Summary of crystallographic data and structure refinement results, ORTEP drawings, atomic coordinates and equivalent isotropic displacement parameters, bond lengths and angles, anisotropic displacement parameters. These data can be found at http://dx.doi.org/10.1016/j.jorganchem.xxxx.xx.xxx.

\section{References}

[1] D. Morales-Morales, C. Grause, K. Kasaoka, R. Redón, R.E. Cramer, C.M. Jensen, Inorg. Chim. Acta 300-302 (2000) 958.

[2] R.B. Bedford, S.M. Draper, P.N. Scully, S.L. Welch, New J. Chem. 24 (2000) 745 .

[3] (a) D. Morales-Morales, Mini Rev. Org. Chem. 5 (2008) 141; (b) J. Choi, A.H.R. MacArthur, M. Brookhart, A.S. Goldman, Chem. Rev. 111 (2011) 1761; (c) N. Selander, K.J. Szabó, Chem. Rev. 111 (2011) 2048; (d) M.C. Haibach, S. Kundu, 
M. Brookhart, A.S. Goldman, Acc. Chem. Res. 45 (2012) 947; (e) D. Zargarian, A. Castonguay, D.M. Spasyuk, Top. Organomet. Chem. 40 (2013) 131; (f) K.J. Szabo, O.F. Wendt, Pincer and Pincer-Type Complexes: Applications in Organic Synthesis and Catalysis. Wiley-VCH. Germany. 2014; (g) G. van Koten, D. Milstein, Organometallic Pincer Chemistry, Springer, Berlin, 2013, vol. 40; (h) D. Morales-Morales, C.M. Jensen, The Chemistry of Pincer Compounds, Elsevier, Amsterdam, 2007; (i) P.A. Chase, G. van Koten, The pincer ligand: its chemistry and applications (Catalytic Science), 1st ed. Imperial College Press, London, 2010 .

[4] (a) I. Göttker-Schnetmann, P. White, M. Brookhart, J. Am. Chem. Soc. 126 (2004) 1804; (b) I. Göttker-Schnetmann, P.S. White, M. Brookhart, Organometallics 23 (2004) 1766.

[5] N. Solin, J. Kjellgren, K.J. Szabó, J. Am. Chem. Soc. 126 (2004) 7026.

[6] (a) W.J. Hunks, M.C. Jennings, R.J. Puddephatt, Inorg. Chem. 39 (2000) 2699; (b)

V. Gómez-Benítez, O. Baldovino-Pantaleón, C. Herrera-Álvarez, R.A. Toscano, D. Morales-Morales, Tetrahedron Lett. 47 (2006) 5059; (c) V. Pandarus, D. Zargarian, Organometallics 26 (2007) 4321; (d) A. Naghipour, S.J. Sabounchei, D. Morales-Morales, D. Canseco-González, C.M. Jensen, Polyhedron 26 (2007) 1445; (e) D. Olsson, A. Arunachalampillai, O.F. Wendt, Dalton Trans. (2007) 5427; (f) M.A. Solano-Prado, F. Estudiante-Negrete, D. Morales-Morales, Polyhedron, 29 (2010) 592.

[7] (a) J. Campora, P. Palma, D. del Rio, E. Alvarez, Organometallics 23 (2004) 1652; (b) J. Campora, P. Palma, D. del Rio, M.M. Conejo, E. Alvarez, Organometallics 23 (2004) 5653; (c) A. Castonguay, C. Sui-Seng, D. Zargarian, A.L. Beauchamp, Organometallics 25 (2006) 602; (d) A. Castonguay, D.M. Spasyuk, N. Madern, A.L. Beauchamp, D. Zargarian, Organometallics, 28 (2009) 2134; (e) A. Castonguay, A.L. Beauchamp, D. Zargarian, Inorg. Chem. 48 (2009) 3177; (f) A.B. Salah, D. Zargarian, Dalton Trans. 40 (2011) 8977; (g) L.M. Martinez-Prieto, C. Melero, D. del Rio, P. Palma, J. Campora, E. Álvarez, Organometallics 31 (2012) 1425; (h) B. Vabre, D.M. Spasyuk, D. Zargarian, 
Organometallics 31 (2012) 8561; (i) S. Murugesan, B. Stöger, M.D. Carvalho, L.P. Ferreira, E. Pittenauer, G. Allmaier, L.F. Veiros, K. Kirchner, Organometallics 33 (2014) 6132; (j) B. Vabre, P. Petiot, R. Declercq, D. Zargarian, Organometallics 33 (2014) 5173; (k) B. Mougang-Soumé, F. Belanger-Gariépy, D. Zargarian, Organometallics 33 (2014) 5990; (1) K.J. Jonasson, O.F. Wendt, Chem. Eur. J. 20 (2014) 11894; (m) J. Hao, B. Vabre, D. Zargarian, Organometallics 33 (2014) 6568.

[8] (a) S. Chakraborty, J.A. Krause, H. Guan, Organometallics 28 (2009) 582; (b) S. Chakraborty, J. Zhang, J.A. Krause, H. Guan, J. Am. Chem. Soc. 132 (2010) 8872; (c) F. Huang, C. Zhang, J. Jiang, Z.-X. Wang, H. Guan, Inorg. Chem. 50 (2011) 3816; (d) S. Chakraborty, Y.J. Patel, J.A. Krause, H. Guan, Polyhedron 32 (2012) 30; (e) S. Chakraborty, J. Zhang, Y.J. Patel, J.A. Krause, H. Guan, Inorg. Chem. 52 (2013) 37; (f) S. Chakraborty, Y.J. Patel, J.A. Krause, H. Guan, Angew. Chem. Int. Ed. 52 (2013) 7523; (g) J. Zhang, C.M. Medley, J.A. Krause, H. Guan, Organometallics 29 (2010) 6393.

[9] J. Zhang, A. Adhikary, K.M. King, J.A. Krause, H. Guan, Dalton Trans. 41 (2012) 7959.

[10]B. Vabre, F. Lindeperg, D. Zargarian, Green Chem. 15 (2013) 3188.

[11]T.J. Schmeier, A. Nova, N. Hazari, F. Maseras, Chem. Eur. J. 18 (2012) 6915.

[12](a) D. Mandal, V. Bertolasi, J. Ribas-Ariño, G. Aromí, D. Ray, Inorg. Chem. 47 (2008) 3465; (b) X.-T. Wang, B.-W. Wang, Z.-M. Wang, W. Zhang, S. Gao, Inorg. Chim. Acta, 361 (2008) 3895; (c) B. Machura, A. Świtlicka, I. Nawrot, J. Mroziński, K. Michalik, Polyhedron 30 (2011) 2815; (d) M. Das, S. Chatterjee, S. Chattopadhyay, Polyhedron 68 (2014) 205.

[13] The relative ratios of the complexes in the metathesis and exchange reactions were all determined from integrations of the ${ }^{31} \mathrm{P}\left\{{ }^{1} \mathrm{H}\right\}$ NMR spectra. For comparison, quantitative inverse gated decoupling NMR spectra were taken for some of the experiments. The two NMR techniques gave the same integration values.

[14]F. De Proft, J.M.L. Martin, P. Geerlings, Chem. Phys. Lett. 256 (1996) 400. 
[15](a) E. Chamorro, P. Pérez, J. Chem. Phys. 123 (2005) 114107; (b) J.I. Martínez-Araya, Chem. Phys. Lett. 506 (2011) 104; (c) D. Qi, L. Zhang, L. Wan, Y. Zhang, Y. Bian, J. Jiang, Phys. Chem. Chem. Phys. 13 (2011) 13277.

[16]J.I. Martinez-Araya, J. Mol. Model. 18 (2012) 4299.

[17]M.J. Frisch et al., Gaussian 09, Revision D. 01, Gaussian Inc., Wallingford CT, 2009. 